\title{
INVESTOR-STATE ARBITRATORS' DUTIES TO NON-PARTIES
}

\author{
PERRY S. BECHKY*
}

The notion that arbitrators owe duties to the parties in investor-state disputes is familiar. This article explores less-trodden terrain. It argues that, notwithstanding the party-centric norms of arbitration, investment arbitrators also owe duties to non-parties. It begins by establishing a beachhead - a clear example of a duty to a non-party, as a proof of concept - before moving into rougher territory. The article catalogs and surveys various duties owed to non-parties, discussing the nature of these duties and how they are enforced. Finally, the article shows that recognizing duties to non-parties both informs a proper understanding of the investment arbitration system and may help improve that system.

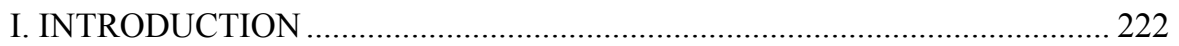

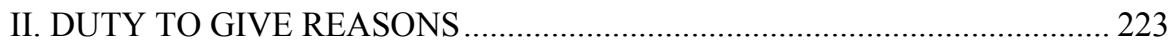

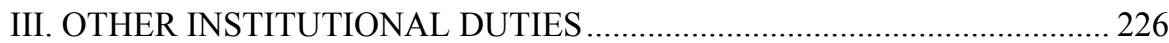

A. Duty to Perform Fundamental Responsibilities .............................. 226

1. Duty to Judge Fairly ............................................................... 229

2. Duty of Impartiality and Independence ................................. 231

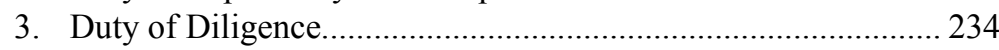

B. Duty to Follow Institutional Requirements ................................... 237

C. Duty of Jurisdictional Policing........................................................ 238

IV. DUTIES TO NON-PARTY PARTICIPANTS …......................................... 240

V. SYSTEMIC DUTIES .......................................................................... 243

A. Duty to Comply with Jus Cogens Norms.................................... 245

Copyright (C) 2021 Perry S. Bechky

* Partner, Berliner Corcoran \& Rowe LLP; Visiting Scholar, Seattle University School of Law. I am grateful for the opportunities to have presented a draft of this article at the American Society of International Law Research Forum at Washington University in St. Louis and the International Conference on the Duties, Rights, and Powers of International Arbitrators at American University. I thank the organizers for inviting me to participate and the participants for their valuable comments, including José Manuel Álvarez Zárate, Julian Arato, Ayelet Berman, Andrea Bjorklund, Charles Brower, Katia Fach Gómez, Yuka Fukunaga, Vera Korzun, Lucinda Low, and David Sloss.

This article was substantially complete in January 2020. Efforts have been made to incorporate certain major developments through September 2020. The views expressed here are my own and should not be attributed to my law firm or any of its clients. All mistakes are my own. 
B. Duty to Respect the United Nations Charter 248

C. Institutional Duties Revisited

VI. WHY DUTIES TO NON-PARTIES MATTER 253

VII. CONCLUSION 257

\section{INTRODUCTION}

Arbitrators in investor-state disputes plainly owe duties to the parties to the case before them. They are appointed to do a job, and they must do that job and do it well: competently, diligently, ethically, expeditiously, fairly, impartially and independently, and properly. They must act with sound judgment, due care, and an open mind.

But, do investor-state arbitrators also owe duties to anyone else? If so, what duties do they owe and to whom? From where do such duties originate? Given that party autonomy is a hallmark of arbitration, can duties to nonparties ever prevail over the will of the parties? How are such duties enforced? And, what does the existence of duties to non-parties mean for the system of international investment arbitration?

The infamous decision in Loewen v. United States shows why these questions need attention. The tribunal found that a Canadian investor suffered a "miscarriage of justice" resulting in a jury verdict in Mississippi of $\$ 500$ million, but nevertheless ruled that this injustice did not deny the investor "fair and equitable treatment." Years later, the arbitrator appointed by the United States said that the U.S. government "put pressure" on him to ensure that it prevailed in the case. ${ }^{2}$ By accepting his appointment under such pressure, the arbitrator deprived the claimant of a just process. Yet, the harms do not end with the claimant. Loewen further denied Canada the benefit of its bargain under the North American Free Trade Agreement ("NAFTA"), which was supposed to give Canadian investors access to "impartial tribunal[s]." 3 The ruling also harmed the system of investor-state arbitration, calling into question its ability to deliver impartial justice. And,

1. Loewen Grp. v. U.S., ICSID Case No. ARB(AF)/98/3, Award, ๆ甲 54, 101, 137, 217, 241-42 (June 26, 2003), 7 ICSID Rep. 442 (2005). Some of the literature criticizing Loewen is listed in JAN PAUlsson, THE IDEA OF ARBITRATION 160, 160 n.27 (2013).

2. David Schneiderman, Judicial Politics and International Investment Arbitration: Seeking an Explanation for Conflicting Outcomes, 30 Nw. J. INT'L L. \& BuS. 383, 405 (2010). Schneiderman quotes the arbitrator recalling the following conversation with the U.S. Department of Justice: "You know, judge ... if we lose this case we could lose NAFTA. Well, if you want to put pressure on me ... then that does it." Id.

3. North American Free Trade Agreement, Can.-Mex.-U.S., art. 1115, Dec. 17, 1992, 32 I.L.M. 605 [hereinafter NAFTA] (establishing an investor-state arbitration system that "assures . . . due process before an impartial tribunal"). 
as Jan Paulsson rightly concluded, the case "subvert[ed] larger interests," including "advancing the international rule of law." "

The Loewen example shows that, while investment arbitration was born from a party-centric tradition, tribunal rulings affect non-parties. Scrutiny is needed of the responsibilities the arbitrators owe those outside the room.

Like others exercising public authority, investment arbitrators must respect the interests of all affected by their decisions. This article thus situates investment arbitrators within the trend towards "otherregardingness" in global administrative law. ${ }^{5}$ Recognizing arbitrators' responsibilities to others should influence the behavior of arbitrators themselves, as well as arbitral institutions and states. In other words, increasing other-regardingness may help deliver the reform that investment arbitration needs.

Part II opens by illustrating a duty to a non-party: tribunals in cases at the International Centre for Settlement of Investment Disputes ("ICSID") owe ICSID, a non-party, the duty to issue written, reasoned awards. ${ }^{6}$ Part III then addresses other duties that investor-state arbitrators owe to arbitral institutions, notably ICSID. Part IV examines arbitrators' duties to nonparty participants in investment cases, including other states and nongovernmental organizations. Part V introduces the concept of systemic duties of investor-state arbitrators. Arbitrators owe systemic duties not to particular persons, but to the creators of the investment arbitration system (states) and its ultimate beneficiaries (the global public). Part VI discusses why it is important to recognize the duties investor-state arbitrators owe to non-parties. Part VII concludes by reflecting on arbitrators' fundamental duty of good faith. ${ }^{7}$

\section{DUTY TO GIVE REASONS}

The ICSID Convention requires arbitrators to produce an award in writing. ${ }^{8}$ Further, " $\left.\mathrm{t}\right] \mathrm{h}$ he award shall deal with every question submitted to the Tribunal, and shall state the reasons upon which it is based."

4. PAULSSON, supra note 1 , at 162.

5. See infra Part VI.

6. Convention on the Settlement of Investment Disputes Between States and Nationals of Other States, art. 48(2), Mar. 18, 1965, 17 U.S.T. 1270, 575 U.N.T.S. 159 [hereinafter ICSID Convention] ("The award of the Tribunal shall be in writing and shall be signed by the members of the Tribunal who voted for it.")

7. This article addresses arbitrators' duties originating from applicable treaties (especially the ICSID Convention and investment treaties), international law, and arbitral rules. It does not address duties that may arise from national law.

8. ICSID Convention, supra note 6 .

9. Id. art. 48(3). 
ICSID arbitrators thus have a duty to write reasoned awards. This duty is "quite unequivocal," "mandatory," and "not subject to the parties" disposition" - it cannot be waived or varied, not even by mutual agreement of the parties. ${ }^{10}$ The drafters of the ICSID Convention considered whether to allow parties to waive the requirement of reasons, but rejected that position by "a large majority" because "the reasons were seen to be too important to allow the parties to waive them."11

Its fixed nature shows that the duty to provide reasons is not owed only to the parties. It is also owed to ICSID itself. The duty arises from ICSID's founding charter, ${ }^{12}$ and reflects ICSID's institutional commitment to reasoned awards, a firm choice that outweighs even the ethos of party autonomy. The International Chamber of Commerce ("ICC") makes the same commitment to reasons. ${ }^{13}$ In contrast, the London Court of International Arbitration ("LCIA"), the Permanent Court of Arbitration ("PCA"), and the Stockholm Chamber of Commerce ("SCC") require written awards but allow the parties to opt out of reasons. ${ }^{14}$

The ICSID Convention creates a mechanism to enforce the duty to write reasoned awards: an award may be annulled if it "has failed to state the reasons on which it is based." 15 This enforcement mechanism is weakened, to be sure, by the fact that it is available only if a party requests annulment ${ }^{16}$ - a limit that suggests that, in theory, the parties and tribunal could jointly depart from the requirement of reasons. Nevertheless, this is less potent than 2009)

10. Christoph H. Schreuer ET AL., The ICSID CONVENTION: A COMMENTARY 996, 998 (2d ed.

11. Id. at 820,996 .

12. See ICSID Convention, supra note 6, art. 48(3).

13. Int'l Chamber of Commerce [ICC], Arbitration Rules, art. 32(2) (Mar. 1, 2017) [hereinafter ICC Rules].

14. Arbitration Inst. of the Stockholm Chamber of Commerce [AISCC], Arbitration Rules, art. 42(1) (Jan. 1, 2017) [hereinafter SCC Rules] ("The Arbitral Tribunal shall make its award in writing, and, unless otherwise agreed by the parties, shall state the reasons upon which the award is based."); London Court of Int'1 Arbitration [LCIA], Arbitration Rules, art. 26.2 (Oct. 1, 2014) [hereinafter LCIA Rules] ("The Arbitral Tribunal shall make any award in writing and, unless all parties agree in writing otherwise, shall state the reasons upon which such award is based."); Permanent Court of Arbitration [PCA], Arbitration Rules, art. 34(2) (Dec. 17, 2012) [hereinafter PCA Rules] ("All awards shall be made in writing ...."); Id. art. 34(3) ("The arbitral tribunal shall state the reasons upon which the award is based, unless the parties have agreed that no reasons are to be given."); see also U.N. COMM'N ON INT'L TRADE LAW, UNCITRAL MODEL LAW ON INTERNATIONAL COMMERCIAL ARBITRATION, arts. 31(1)-(2), U.N. Sales No. E.08.V.4 (2006) [hereinafter UNCITRAL MODEL LAW] ("The award shall state the reasons upon which it is based, unless the parties have agreed that no reasons are to be given or the award is an award on agreed terms under article 30.”).

15. ICSID Convention, supra note 6, art. 52(1)(e). For an introduction to ICSID annulment proceedings and the role of ad hoc committees, see generally Int'l Ctr. for Settlement of Inv. Disputes [ICSID], Background Paper on Annulment for the Administrative Council of ICSID (Aug. 10, 2012).

16. ICSID Convention, supra note 6, art. 52(1). 
it appears. It only protects an unreasoned award where both parties refrain from requesting annulment. Christoph Schreuer argues that, "[a]n agreement between the parties to the effect that reasons need not be stated would be invalid and would not preclude a subsequent application for annulment on this ground." $" 17$

Moreover, ICSID can informally enforce the reasons requirement through its power of appointment. ICSID appoints all members of annulment committees, presidents of tribunals in cases where the parties cannot agree, and non-presiding arbitrators in cases where a party (usually the respondent) fails to appoint an arbitrator. ${ }^{18}$ An arbitrator who failed to produce a reasoned award, in violation of the ICSID Convention, could hardly expect to secure future appointments. The threat of losing future appointments creates a powerful compliance incentive. As Catherine Rogers has observed, institutional control over appointments is "the primary means through which arbitrators are regulated."19 In the case of ICSID in particular, this power is enhanced by both the prestige and number of ICSID appointments.

To conclude, the duty to write reasoned awards arises from the ICSID Convention. It serves ICSID's institutional interests. It cannot be waived or varied. It can be enforced by ICSID. It should therefore be understood as a duty owed to ICSID. This is not to claim that the duty of reasoned awards is owed only to ICSID. It serves party interests, ${ }^{20}$ and it is enforceable by the parties. It is best understood as a mixed duty, owed to both the parties and ICSID.

17. SCHREUER ET AL., supra note 10, at 996-97 (quoting Maritime Int'l Nominees Establishment v. Republic of Guinea, ICSID Case No. ARB/84/4, Decision on Annulment, 95.10 (Dec. 22, 1989), 4 ICSID Rep. 79 (1997)). One may speculate what would happen if a party agreed to an unreasoned award and then requested annulment for lack of reasons - perhaps annulment of the unreasoned award plus an assignment of costs against the party for prolonging and complicating the case.

18. ICSID Convention, supra note 6 , arts. 37(2)(b), 38. Such appointments are made by the President of the World Bank, acting in the President's capacity as Chairman of the ICSID Administrative Council. Id. art. 5.

19. CATHERINe A. Rogers, Ethics In InTERnAtional ARbitration 240 (2014).

20. See, e.g., Lon L. Fuller, The Forms and Limits of Adjudication, 92 HARV. L. REV. 353, 388 (1978) ("By and large it seems clear that the fairness and effectiveness of adjudication are promoted by reasoned opinions. Without such opinions the parties have to take it on faith that their participation in the decision has been real, that the arbiter has in fact understood and taken into account their proofs and arguments.”) (emphasis added); Fraport AG Frankfurt Airport Servs. Worldwide v. Republic of the Phil., ICSID Case No. ARB/03/25, Decision on the Application for Annulment of Fraport AG Frankfurt Airport Services Worldwide, 9250 (Dec. 23, 2010) ("Reasons are important to the legitimacy of the decision. . . . The parties will want to assure themselves as to how the Tribunal reached its conclusions and whether such conclusions can be challenged before an ad hoc committee.") (emphasis added). 


\section{OTHER INSTITUTIONAL DUTIES}

As seen in Part II, when an arbitral institution mandates rules that cannot be waived or varied by the parties, the institution strongly signals the existence of duties owed to the institution itself. Thus, this Part considers other fixed rules that institutions impose on arbitrators, the institutional interests these rules serve, and how the rules are enforced. Specifically, it examines three categories of fixed rules: (a) the duty to perform fundamental responsibilities, a category that includes a number of specific responsibilities; (b) the duty to follow institutional requirements; and (c) the duty of jurisdictional policing.

\section{A. Duty to Perform Fundamental Responsibilities}

Owen Fiss has articulated the central duty of judges, equally apt to arbitrators: they must listen and then they must speak. ${ }^{21}$ A tribunal must neither speak (i.e., render a decision) without truly listening to the parties' arguments and evidence nor, having finished listening, fail to speak. ${ }^{22}$

Simply rendering an award may be the most basic responsibility of a tribunal, but rendering an award is not enough. Tribunals have an overarching duty to produce an award that is valid and enforceable, which requires that the award follow from a fair process. As stated by the ICSID tribunal in Hrvatska Elektroprivreda, d.d. v. Slovenia (HEP), "The Tribunal's obligation as guardian of the legitimacy of the arbitral process is to make every effort to ensure that the Award is soundly based and not affected by procedural imperfection." "23 The ICC, LCIA, and SCC similarly require that the tribunal "shall make every effort to make sure that the award

21. Owen M. Fiss, Foreword, The Forms of Justice, 93 HARV. L. REV. 1, 14 (1979) ("The judge is required to listen and to speak, and to speak in certain ways."). Fiss added:

The judge is entitled to exercise power only after he has participated in a dialogue .... with very special qualities .... (b) Judges do not have full control over whom they must listen to. They are bound by rules requiring them to listen to a broad range of persons or spokesmen. (c) Judges are compelled to speak back, to respond to the grievance or the claim, and to assume individual responsibility for that response. (d) Judges must also justify their decisions. Id. at 13 .

22. Speaking without listening first is grounds to annul an ICSID award:

[T] he Tribunal's [order] . . . was incompatible with the fundamental obligation on the Tribunal to permit both parties to present their case in relation to the new material. ... The Tribunal ought not to have proceeded to analyse and consider this evidence itself in its deliberations without having afforded the parties the opportunity to make submissions on it, and availed itself of the benefit of those submissions.

Fraport AG Frankfurt Airport Servs. Worldwide, ICSID Case No. ARB/03/25, ๆ 230.

23. Hrvatska Elektroprivreda, d.d. v. Republic of Slovn., ICSID Case No. ARB/05/24, Tribunal's Ruling, $\mid 15$ (May 6, 2008), 24 ICSID Rev. 201 (2009). 
is enforceable at law." 24 And the Restatement on International Arbitration also mentions an arbitrator's "duty to render an enforceable award.",25

Support for the idea that arbitrators have an overarching duty to perform their fundamental responsibilities can also be seen in the debate over the scope of immunity that arbitrators should enjoy from civil liability. Susan Franck, for example, proposed allowing for civil liability against arbitrators in two circumstances:

(a) An arbitrator shall be liable if she/he unjustifiably fails to render an arbitral award. (b) An arbitrator shall be liable for bad-faith conduct done in his/her capacity as an arbitrator. Bad-faith conduct may involve an intentional act that is based upon, but not limited to, fraud or corruption. ${ }^{26}$

The LCIA and SCC both allow civil liability in limited circumstances. ${ }^{27}$ The Restatement, which reflects the dominant position in U.S. law, adheres to

24. ICC Rules, supra note 13, art. 42; accord id. art. 34 (requiring the ICC Court to approve a draft award "as to its form" and also allowing the Court to "draw [the tribunal's] attention to points of substance"); LCIA Rules, supra note 14, art. 32.2 ("For all matters not expressly provided in the Arbitration Agreement . . the Arbitral Tribunal . . . shall make every reasonable effort to ensure that any award is legally recognised and enforceable at the arbitral seat."); SCC Rules, supra note 14, art. 2(2) ("[S]hall make every reasonable effort to ensure that any award is legally enforceable.").

25. Restatement (ThiRd) OF THE U.S. LAW OF INT'L COMMERCIAL \& INV'R-STATE ARBITRATION $\S 4.13$, Reporters' note d (AM. LAW InST., Proposed Final Draft 2019). The Restatement takes the position that a tribunal's material deviation from procedures agreed upon by the parties may warrant invalidation by a reviewing court. $I d$. $\S 4.13$. Explaining the concept of materiality in this context, the Restatement argues:

[A] court may consider whether such deviation was a justifiable exercise of arbitrator discretion. For example, an intentional deviation from the parties' agreed-upon procedures to protect the safety of the parties, to ensure the enforceability of the award, or to comply with the mandatory law of the seat (a violation of which might trigger set aside of the award) would not ordinarily be considered a material violation of the parties' agreement. Although such deviation may violate certain provisions of the parties' agreement, it arguably is intended to serve the parties' larger purposes in submitting their dispute to arbitration and within the arbitrators' discretion and duty to render an enforceable award.

Id. $\S 4.13$, Reporters' note d (emphasis added); see also id. $\S 4.13 \mathrm{cmt}$. d.

26. Susan D. Franck, The Liability of International Arbitrators: A Comparative Analysis and Proposal for Qualified Immunity, 20 N.Y.L. SCH. J. INT'L \& COMP. L. 1, 58 (2000).

27. See LCIA Rules, supra note 14, art. 31.1 (barring arbitrator liability except when there is evidence of "conscious and deliberate wrongdoing"); SCC Rules, supra note 14, art. 52 (barring arbitrator liability except for acts or omissions attributable to "wilful misconduct or gross negligence"). While UNCITRAL allows arbitrator liability for "intentional wrongdoing" and the PCA Rules are rooted in the UNCITRAL Rules, the PCA departs on this point by precluding arbitrator liability "to the fullest extent permitted under the applicable law." Compare U.N. Comm'n on Int'l Trade Law, UNCITRAL Arbitration Rules, art. 16 (2013) [hereinafter UNCITRAL Arbitration Rules], https://uncitral.un.org/ sites/uncitral.un.org/files/media-documents/uncitral/en/uncitral-arbitration-rules-2013-e.pdf [https://per ma.cc/6B9T-5XJM] (excluding “intentional wrongdoing” from parties' wavier of arbitrator liability), with PCA Rules, supra note 14, art. 16 ("[Stipulating] parties waive [arbitrator liability], to the fullest extent permitted under the applicable law ....”). The ICC aligns with the PCA in affording arbitrator immunity except as "prohibited by applicable law.” ICC Rules, supra note 13, art. 41. 
absolute immunity, ${ }^{28}$ but notes that some U.S. courts have allowed arbitrator liability for "failure to render an award" or "when arbitrator misconduct is so extreme that any arbitral outcome is not part of a legitimate deliberative

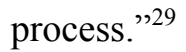

The duty to perform is owed to parties, of course - failure deprives the parties of the process they establish and pay for. ${ }^{30}$ It is owed to institutions as well. As Rogers observes, institutions exercise regulatory powers over arbitrators to "ensure[] that institutions are not obliged to administer arbitrations that are likely to produce unenforceable awards or otherwise lack legitimacy," because "the interests and functions of arbitral institutions are beyond mere facilitation of party preferences." 31 Indeed, institutions have a paramount interest in ensuring the legitimacy and enforceability of

28. RESTATEMENT (ThIRD) OF THE U.S. LAW OF INT'L COMMERCIAL \& INV'R-STATE ARBITRATION § 3.10. The Restatement goes so far as to confirm expressly that absolute civil (but not criminal) immunity holds even where arbitrators engage in such gross misconduct as bribery. Id. $\S 3.10$ cmt. b, illus. 2. An earlier draft of the Restatement flirted with cabining immunity, suggesting that arbitrators could be held accountable for "failure to perform fundamental duties (such as failing to render an award)" and for breaching "related implied obligations to refrain from extreme misconduct that endangers the validity of the award or its enforceability." RESTATEMENT OF THE U.S. LAW OF INT'L COMMERCIAL ARbitration $\S 3.10 \mathrm{cmt}$. b (AM. LAW InST., Preliminary Draft 9 2016) (emphasis added). The draft added, "arbitrators and arbitral institutions are employed through contractual arrangements ... ." Id. "Although the precise contours and nature of the arbitrator's contract remain somewhat amorphous, the contract unequivocally involves remuneration in exchange for certain services and the obligations that accompany them." Id. (emphasis added). The final Restatement dropped this language, apparently due to pragmatic concerns. See RESTATEMENT (THIRD) OF THE U.S. LAW OF INT'L COMMERCIAL \& INV'R-STATE ARBITRATION $\S 3.10$, Reporters' note a (arguing that absolute immunity prevents collateral attacks on awards and encourages individuals to serve as arbitrators); Caroline Simson, Restatement Looks to Resolve Divisive Int'l Arbitration Issues, LAw360 (Nov. 20, 2019, 9:57 PM), https:// www.law360.com/articles/1222072/restatement-looks-to-resolve-divisive-int-1-arbitration-issues [https: //perma.cc/ZY5M-JDJM] (citing Catherine Rogers, an associate reporter of the Restatement, who attributed the change to concerns about the difficulty of obtaining insurance for arbitrator liability). Even without admitting civil liability for breaches, however, the final Restatement continues to recognize arbitrators' core "duty to render an enforceable award." See RESTATEMENT (THIRD) OF THE U.S. LAW OF INT'L COMMERCIAL \& INV’R-STATE ARBITRATION $§ 4.13$, Reporters' note d.

29. RESTATEMENT (THIRD) OF THE U.S. LAW OF INT'L COMMERCIAL \& INV'R-STATE ARBITRATION $\S 3.10$, Reporters' note b (quoting Ernst, Inc. v. Manhattan Constr. Co. of Tex., 551 F.2d 1026, 1033 (5th Cir. 1977) (finding no immunity for "failure to decide" because the arbitrator "has simply defaulted on a contractual duty to both parties"), aff'd on other grounds, 559 F.2d 268 (5th Cir. 1977)).

30. Cf. Peter B. Rutledge, Toward a Contractual Approach for Arbitral Immunity, 39 GA. L. REV. 151, 154 (2004) (“[A]rbitrators are private professionals retained to perform services."); REDFERN AND HUNTER ON INTERNATIONAL ARBITRATION para. 5.49 (Nigel Blackaby et al. eds., 6th ed. 2015) ("The parties to an arbitration entrust an arbitral tribunal with an important task for which they are prepared to pay-often quite generously. They therefore expect the arbitrator to perform the task with due care and there exists an obvious moral duty for him or her to do so. The question is whether there is also a legal duty."). The ensuing discussion shows that Redfern and Hunter equate "legal duty" with civil liability and answer that liability is available for at least some serious failures to act with due care in all countries but the United States. Id. paras. 5.49-.55.

31. ROGERS, supra note 19 , at 82 (emphasis added). 
awards issued under their auspices. No arbitral institution could survive if its awards came to be perceived as illegitimate or unenforceable. ${ }^{32}$ Institutions depend on voluntary consent by potential parties and are thus (like arbitrators themselves) "dealing in virtue." 33 To paraphrase Iago: good name in an arbitral institution is the jewel of their souls; he that filches the institution's good name makes it poor indeed. ${ }^{34}$

Arbitrators cannot be allowed to subvert an institution's reputation for integrity - even if they act according to the parties' agreement. To guard against grave negative externalities, party autonomy must yield to the institution's needs. This is a classic case for regulatory intervention.

Accordingly, institutions impose non-variable duties to ensure that arbitrators perform their fundamental responsibilities. Some of those responsibilities are reviewed below: (1) the duty to judge fairly; (2) the duty of impartiality and independence; and (3) the duty of diligence.

\section{Duty to Judge Fairly}

ICSID mandates that "each arbitrator shall sign a declaration" in an exact specified form, which pledges:

I shall judge fairly as between the parties, according to the applicable law, and shall not accept any instruction or compensation with regard to the proceeding from any source except as provided in the [ICSID Convention] and in the Regulations and Rules made pursuant thereto. ${ }^{35}$

ICSID enforces the declaration requirement through a simple mechanism: "Any arbitrator failing to sign a declaration by the end of the first session of the Tribunal shall be deemed to have resigned." 36 Plus,

32. $C f$. Restatement (ThiRd) OF the U.S. LAw OF InT'L COMMERcial \& INV'R-STATE ARBITRATION § 3.10, Reporters' note b (quoting In re Nat'l Forum Trade Practices Litig., 704 F. Supp. $2 \mathrm{~d}$ at 837 ) ("[I]nstitutional immunity may not apply and suit may proceed based on allegations of 'systemic, pervasive, and far-reaching allegations of bias and corruption, rendering every single arbitration performed by provider suspect."').

33. See generally Yves Dezalay \& Bryant G. Garth, Dealing in Virtue: International COMMERCIAL ARBITRATION AND THE CONSTRUCTION OF A TRANSNATIONAL LEGAL ORdER (1996) (explaining how reputation for virtue aids in the competition for arbitral appointments).

34. William ShaKeSPeARE, Othello act 3, sc. 3. Let us leave aside here the question of Iago's sincerity.

35. Int'l Ctr. for Settlement of Inv. Disputes [ICSID], The Rules of Procedure for Arbitration Proceedings (The Arbitration Rules) of ICSID, r. 6(2) (Apr. 10, 2006) [hereinafter ICSID Rules] (emphasis added). ICSID has proposed a thorough update of its rules, but this article only notes the proposals where they would work substantive changes relevant to the arbitrators' duties. See generally Int'1 Ctr. for Settlement of Inv. Disputes [ICSID], Proposals for Amendment of the ICSID Rules (Feb. 28, 2020) [hereinafter ICSID Proposals]. The proposals would make the arbitrator declaration more detailed and specific, preserving the obligation to "judge fairly." Id. at 241.

36. ICSID Rules, supra note 35, r. 6(2) (emphasis added). ICSID has proposed to replace the deemed-resignation rule with another enforcement mechanism: failure to sign the declaration prevents 
failure to judge fairly is grounds for annulment. ${ }^{37}$ ICSID also presumably enforces the obligation to judge fairly through control of subsequent appointments - a breach of this core responsibility would call into doubt whether the arbitrator has the characteristics needed for appointment, "high moral character and recognized competence." ${ }^{38}$

Similar commitments to basic fairness dot the arbitral landscape. Historically, some ancient Greek arbitrators swore, "By Zeus and Lycian Apollo and Earth, I will judge the case ... in accordance with the justest judgment. ..."39 Likewise, the Jay Treaty of 1794 required arbitrators to "solemnly swear (or affirm)" to decide all cases "according to Justice and Equity." 40 Today, the ICC and LCIA both oblige arbitrators to "act fairly," with the LCIA expressly wrapping its rule in the language of arbitrator's duties. ${ }^{41}$ The LCIA highlights the institutional nature of this duty of fairness by empowering the LCIA Court to remove an arbitrator who acts unfairly "upon its own initiative."

acceptance of the appointment and triggers a process to make a new appointment. ICSID Proposals, supra note 35 , r. 19(3)-(5), at 39.

37. ICSID Convention, supra note 6, arts. 52(1), (3). At least three grounds for annulment may be implicated by an arbitrator's failure to judge fairly, at least where the failure is sufficiently serious: annulment where "the Tribunal was not properly constituted," where "there was corruption on the part of a member of the Tribunal," and where "there has been a serious departure from a fundamental rule of procedure." See SCHREUER ET AL., supra note 10, at 979-91.

38. ICSID Convention, supra note 6, arts. 14(1), 40(2), 57.

39. Gary B. Born, International Arbitration: CASES ANd Materials 742 (2d ed. 2015) (quoting Marcus Niebuhr Tod, InTERnational ARbitration AmONGST the Greeks 115-16 (1913)).

40. Treaty of Amity Commerce and Navigation, Gr. Brit.-U.S., art. 6, Nov. 19, 1794, 8 Stat. 116 [hereinafter Jay Treaty] ("Commissioners . . . shall . . . take the following Oath or Affirmation . . . -viz.I . . do solemnly swear (or affirm) that I will honestly, diligently, impartially, and carefully examine, and to the best of my Judgement, according to Justice and Equity decide all such Complaints . . . and that I will forbear to act as a Commissioner in any Case in which I may be personally interested.").

41. LCIA Rules, supra note 14, art. 14.4 ("[T] he Arbitral Tribunal's general duties at all times during the arbitration shall include: (i) a duty to act fairly and impartially as between all parties, giving each a reasonable opportunity of putting its case and dealing with that of its opponent(s) ...."); ICC Rules, supra note 13, art. 22(4) ("In all cases, the arbitral tribunal shall act fairly and impartially and ensure that each party has a reasonable opportunity to present its case.”).

42. LCIA Rules, supra note 14, art. 10.1 ("The LCIA Court may revoke any arbitrator's appointment upon its own initiative, at the written request of all other members of the Arbitral Tribunal or upon a written challenge by any party if . . that arbitrator . . becomes . . . unfit to act ...."); id. art. 10.2 ("The LCIA Court may determine that an arbitrator is unfit to act under Article 10.1 if that arbitrator ... does not act fairly or impartially as between the parties ...."). 
2. Duty of Impartiality and Independence

The arbitrator's duty of impartiality and independence is a cornerstone of investor-state arbitration, like all international arbitration. ${ }^{43}$ The International Bar Association ("IBA") ethical guidelines describe "[a] fundamental principle... that each arbitrator must be impartial and independent of the parties... during the entire course of the arbitral proceeding. ${ }^{" 44}$ This principle is widely reflected in institutional rules, ${ }^{45}$ and its historical antecedents reach back at least as far as the Jay Treaty. ${ }^{46}$ Moreover, institutions routinely enforce this obligation by requiring every arbitrator to disclose - both initially and throughout the case - any circumstances that could "give rise to reasonable doubts" about the arbitrator's impartiality and independence. ${ }^{47}$

Institutions are so concerned with preserving the impartiality and independence of tribunals operating under their auspices that "several institutions also reserve to themselves the right to refuse to appoint an arbitrator that the institution deems is unsuitable, even if the parties have agreed to the appointment." 48 For example, the ICC and LCIA confirm arbitrators nominated by the parties, and those institutional checks expressly address the nominees' impartiality. ${ }^{49}$ Although ICSID does not scrutinize

43. See, e.g., Int'l Ctr. for Settlement of Inv. Disputes [ICSID] \& U.N. Comm'n on Int'1 Trade Law [UNCITRAL], Draft Code of Conduct for Adjudicators in Investor-State Dispute Settlement, art. 3, para. 27 (May 1, 2020) [hereinafter Draft Code] (describing impartiality and independence as "key to every system of justice").

44. Int'1 Bar Ass'n Res. IBA Guidelines on Conflicts of Interest in International Arbitration, at 4 (Oct. 23, 2014).

45. See, e.g., ICC Rules, supra note 13, art. 11(1) ("Every arbitrator must be and remain impartial and independent of the parties involved in the arbitration.”); LCIA Rules, supra note 14, art. 5.3 ("All arbitrators shall be and remain at all times impartial and independent of the parties; and none shall act in the arbitration as advocate for or representative of any party."); PCA Rules, supra note 14, art. 11, annex ("I am impartial and independent ... and intend to remain so."); SCC Rules, supra note 14, art. 18(1) ("Every arbitrator must be impartial and independent."). The English version of ICSID Convention Article 14 refers to "independent judgment," while the Spanish version mentions "imparcialidad de juicio," leading to the conclusion that "Article 14 encompasses challenges made on the basis of the absence of independence or impartiality." See Meg Kinnear \& Frauke Nitschke, Disqualification of Arbitrators Under the ICSID Convention and Rules, in CHALLENGES AND RECUSALS OF JUDGES AND ARBITRATORS IN INTERNATIONAL COURTS AND TRIBUNALS 50 (Chiara Giorgetti ed., 2015).

46. See Jay Treaty, supra note 40, art. 6. I thank Bjorn Arp for this observation.

47. See ICC Rules, supra note 13, art. 11(2); see also ICSID Rules, supra note 35, r. 6; LCIA Rules, supra note 14, arts. 5.4-.5.

48. ROGERS, supra note 19 , at 82 .

49. ICC Rules, supra note 13, art. 13(2) ("The Secretary General may confirm... persons nominated by the parties ... provided that the statement they have submitted contains no qualification regarding impartiality or independence or that a qualified statement regarding impartiality or independence has not given rise to objections. . . If the Secretary General considers that a [nominee] . . should not be confirmed, the matter shall be submitted to the Court.”); LCIA Rules, supra note 14, art. 7.1 ("If the parties have agreed howsoever that any arbitrator is to be appointed by one or more of them ... 
party appointments in this manner, it nevertheless requires that arbitrators must be "persons of high moral character ... who may be relied upon to exercise independent judgment," 50 and enforces that requirement through the mandatory declaration, institutional appointments, annulments, and other mechanisms discussed above. Moreover, all the institutions have mechanisms for disqualifying arbitrators who are not, or cease to be, impartial and independent. ${ }^{51}$

The duty of impartiality and independence is mandatory. ${ }^{52}$ Parties may not vary it in favor of the "traditional" U.S. approach, where impartiality was expected only of the third, "neutral" arbitrator - an approach that "has long been considered unacceptable in international arbitration." ${ }^{, 53}$ To the contrary, the ICSID Convention requires impartiality and independence of all arbitrators. ${ }^{54}$ Schreuer identifies this provision as one of the Convention's "mandatory rules concerning the composition of the tribunal which may not be departed from" and he suggests that "application by a tribunal of agreed rules that violate such fundamental principles could expose an award to annulment."55 Likewise, reviewing courts may refuse to confirm or recognize non-ICSID investment awards in cases of "evident partiality.",56

that agreement shall be treated... as an agreement to nominate an arbitrator for all purposes. Such nominee may only be appointed by the LCIA Court as arbitrator subject to that nominee's compliance with Articles 5.3 to 5.5 [concerning impartiality and independence, and related disclosures]; and the LCIA Court shall refuse to appoint any nominee if it determines that the nominee is not so compliant or is otherwise unsuitable.").

50. ICSID Convention, supra note 6, arts. 14(1), 40(2).

51. Id. arts. 57-58; ICC Rules, supra note 13, arts. 14-15(1); LCIA Rules, supra note 14, arts. $10.1-.2$.

52. Indeed, S.I. Strong contends that impartiality and independence of arbitrators and judges rises to the level of a jus cogens norm. See S.I. Strong, General Principles of Procedural Law and Procedural Jus Cogens, 122 PA. ST. L. REV. 347, 400-01 (2018). For more on jus cogens, see infra Part V.A.

53. ROGERS, supra note 19 , at 324.

54. ICSID Convention, supra note 6, art. 40(2) (requiring party-appointed arbitrators not on ICSID Panels to have the same qualities demanded of Panel members in Article 14(1), including independent judgment).

55. SChreUER ET AL., supra note 10, at 679. To elaborate, Article 44 permits parties to deviate from the Arbitration Rules, but Schreuer explains that this permission is limited by mandatory aspects of the Convention and "certain international minimum standards of fair procedure ... ." Id. ICSID has proposed amendments to its Arbitration Rules confirming this approach: "The Tribunal shall apply any agreement of the parties on procedural matters to the extent that it does not conflict with the Convention or the Administrative and Financial Regulations." See ICSID Proposals, supra note 35, r. 1(2), at 32.

56. See Restatement (Third) OF THE U.S. LAW OF INT'L COMMERCIAL \& INV'R-STATE ARBITRATION § 4.18(a) (AM. LAW InST., Proposed Final Draft 2019). The Restatement takes a view that "[a] showing of evident partiality requires proof that would cause an objective, disinterested observer who is fully informed of the relevant facts relating to the arbitrator's conduct or alleged conflicts of interest to have a serious doubt regarding the fundamental fairness of the arbitral proceedings." Id. $\S$ 4.18(b). Among the factors to be considered by the reviewing court is whether the arbitrator satisfied the "duty to conduct a reasonable investigation into potential conflicts." Id. $\S 4.18$, Reporters' note b. 
In HEP v. Slovenia, the respondent disclosed, shortly before the merits hearing, that its legal team at the hearing would include a barrister from the same chambers as the tribunal's president. ${ }^{57}$ The claimant objected and the tribunal agreed that the late revelation created an "appearance of impropriety and thus an unacceptable situation." 58 At the same time, "the cost and delay implications" of the president's withdrawal at that stage "were apparent to all." "59 Withdrawal would also invite parties to engage in gamesmanship "to frustrate or slow down the proceedings."60 The tribunal thus concluded that, in the circumstances before it, excluding the barrister from the case was "both necessary and appropriate" because the tribunal was "compelled... to preserve the integrity of the proceedings and, ultimately, its Award." $" 61$ The HEP tribunal invoked its "inherent power to take measures to preserve the integrity of its proceedings." ${ }^{62}$ HEP therefore put the integrity of the award and "the legitimacy of the[] proceedings" ahead of a party's acknowledged interest in choosing its legal team. ${ }^{63}$

In so doing, HEP illustrates how a tribunal should prioritize the overarching duty to produce a valid, enforceable award based on legitimate proceedings. To be sure, the tribunal acted only in response to the motion of a party, and it did not expressly tie its decision to ICSID's institutional interests. But its reasoning leans on institutional concerns and demonstrates legitimacy's potential as an operating principle. In other words, HEP implies that ICSID has an institutional interest in impartiality (and more generally in integrity and legitimacy) and that ICSID's interests do and should influence tribunals. After all, it is instructive to consider the alternative: ICSID would have borne the reputational costs if the tribunal had acknowledged the "unacceptable situation" but declined to remedy it. ${ }^{64}$ Institutions need

57. Hrvatska Elektroprivreda, d.d. v. Republic of Slovn., ICSID Case No. ARB/05/24, Tribunal's Ruling, \ 3 (May 6, 2008), 24 ICSID Rev. 201 (2009).

58. Id. 921 (internal quotation marks omitted).

59. Id. $₫ 16$.

60. Id. ๆ 27 (quoting Aron Broches).

61. Id. ๆๆ $30,33$.

62. Id. 933 (invoking ICSID Convention, art. 44 and implied powers of any international tribunal).

63. Id. ๆq 22, 24-26. But see Rompetrol Grp. N.V. v. Rom., ICSID Case No. ARB/06/3, Decision of the Tribunal on the Participation of a Counsel, 15 (Jan. 14, 2010), 24 ICSID Rev. 232 (2009) (declining to follow HEP on the ground that a tribunal's inherent power should be "exercised only in extraordinary circumstances ... which genuinely touch on the integrity of the arbitral process ....").

64. Hrvatska Elektroprivreda, d.d., 24 ICSID Rev. I 21; cf. William W. Burke-White, The Argentine Financial Crisis: State Liability Under BITs and the Legitimacy of the ICSID System, 3 ASIAN J. WTO \& INT'L HEALTH L. \& POL'Y 199, 224-28 (2008) (discussing the controversy over CMS Annulment, where the committee found the award contained manifest errors of law but held that these errors did not warrant annulment under the governing legal standards). 
tribunals to act "as guardian[s] of the legitimacy of the arbitral process" and HEP heeded the call. ${ }^{65}$

\section{Duty of Diligence}

Arbitrators must conduct proceedings diligently, another aspect of the duty to perform fundamental responsibilities. Most institutions set forth the requirement of arbitrator diligence in mandatory terms. For example, the SCC commands, "In all cases, the Arbitral Tribunal shall conduct the arbitration in an impartial, efficient and expeditious manner...." Meanwhile, the LCIA expressly uses the language of duty:

[T]he Arbitral Tribunal's general duties at all times during the arbitration shall include:... (ii) a duty to adopt procedures suitable to the circumstances of the arbitration, avoiding unnecessary delay and expense, so as to provide a fair, efficient and expeditious means for the final resolution of the parties' dispute. ${ }^{67}$

While ICSID has not previously addressed the duty of diligence, its proposed rules would fill that gap with a new "general duty" governing tribunals and parties alike. ${ }^{68}$ ICSID arbitrators would have to "use best efforts" to comply with time limits specified in the ICSID Rules and hold parties to deadlines. ${ }^{69}$ They also would be required to declare:

8 I have sufficient availability to perform my duties as arbitrator in an expeditious and cost-effective manner and in accordance with the time limits in the applicable arbitration rules.

...

9 I confirm that I will not accept new commitments that would conflict with or interfere with my capacity to perform my duties in this arbitration. $^{70}$

On a related note, arbitrators must be willing and able to participate in the arbitral proceedings and in preparing the award. ICSID addresses this concern by enabling parties to move to disqualify an arbitrator who has become "incapacitated or unable to perform the duties of his [or her]

65. Hrvatska Elektroprivreda, d.d., 24 ICSID Rev. ๆ 15.

66. SCC Rules, supra note 14, art. 23(2) (emphasis added); accord PCA Rules, supra note 14, art. 17(1) ("The arbitral tribunal... shall conduct the proceedings so as to avoid unnecessary delay and expense and to provide a fair and efficient process for resolving the parties' dispute."); ICC Rules, supra note 13, art. 22(1) ("The arbitral tribunal and the parties shall make every effort to conduct the arbitration in an expeditious and cost-effective manner... ."); see also SCC Rules, supra note 14, art. 2(1) ("Throughout the proceedings, the SCC, the Arbitral Tribunal and the parties shall act in an efficient and expeditious manner.").

67. LCIA Rules, supra note 14, art. 14.4.

68. ICSID Proposals, supra note 35, r. 3(1), at 33 ("The Tribunal and the parties shall conduct the proceeding in good faith and in an expeditious and cost-effective manner.").

69. Id. rs. $11,12(1)$, at 36 .

70. Id. at 242 . 
office."71 The ICC and LCIA go further, each empowering its court to remove an arbitrator on its "own initiative" where an arbitrator "refuses or becomes unable or unfit to act," including where an arbitrator fails to act with "reasonable efficiency, diligence and industry.",72

Following the proceedings, arbitrators must render awards without undue delay. ICSID, the ICC, and the SCC address this concern by setting deadlines for tribunals to issue awards: about six months. ${ }^{73}$ The UN Commission on International Trade Law ("UNCITRAL") Model Law authorizes courts to terminate the appointment of an arbitrator who becomes "unable to perform his [or her] functions or for other reasons fails to act without undue delay ....",74

While ICSID has demonstrated its interest in timely awards, it has not yet made this an institutional duty. The 180-day rule appears in the ICSID Arbitration Rules, not in the ICSID Convention, and parties may depart from the Arbitration Rules. ${ }^{75}$ By contrast, the ICC and SCC deadlines may be extended only with the approval of the ICC Court and SCC Board, restrictions that assure that the institutional interest in promptness will be duly considered. ${ }^{76}$ ICC parties may "shorten" time limits, but not extend

71. ICSID Rules, supra note 35, r. 8(1); accord PCA Rules, supra note 14, art. 12(3) ("In the event that an arbitrator fails to act or in the event of the ... impossibility of his or her performing his or her functions, the procedure in respect of the challenge of an arbitrator . . . shall apply."). In practice "there has never been a disqualification" under Rule $8(1)$, because "[u]sually arbitrators resign on their own initiative if they became unable to perform the duties of office." Kinnear \& Nitschke, supra note 45, at 51.

72. LCIA Rules, supra note 14, arts. 10.1-.2. The ICC Rule is similar, allowing removal when the Court "decides that the arbitrator is prevented ... from fulfilling the arbitrator's functions, or that the arbitrator is not fulfilling those functions in accordance with the Rules or within the prescribed time limits." ICC Rules, supra note 13, art. 15(2). The SCC provides for its Board of Directors to release an arbitrator who is "unable or fails to perform the arbitrator's functions," without stating expressly whether the Board may exercise that power on its own initiative, although self-initiation may be implied in the rule setting forth the functions of the Board. SCC Rules, supra note 14, art. 20(1)(iii); see id. app. I, art. 6 (listing the "removal of arbitrators" as a function of the Board).

73. Compare ICC Rules, supra note 13, art. 31 (setting the time limit at six months, extendable only by the ICC Court, not by the tribunals themselves), with ICSID Rules, supra note 35, r. 46 (setting the time limit at 120 days, extendable by the tribunal up to 60 days), and SCC Rules, supra note 14, art. 43 ("The final award shall be made no later than six months[, extendable by the SCC Board of Directors ] ... . upon a reasoned request from the Arbitral Tribunal or if otherwise deemed necessary."). ICSID has proposed a new timetable in which most awards will be due in 240 days, but with deadlines of only 60 and 180 days in certain circumstances. ICSID Proposals, supra note 35, r. 58, at 61-62.

74. UNCITRAL MODEL LAW, supra note 14, art. 14(1).

75. ICSID Convention, supra note 6, art. 44. This distinction between the Convention and the Arbitration Rules is discussed further infra Part III.B. For limitations on the freedom to vary the Arbitration Rules, see supra note 55 and accompanying text.

76. ICC Rules, supra note 13, art. 31(2); SCC Rules, supra note 14, art. 43. 
them. $^{77}$ The ICC is also known to use its powers over appointments and arbitrator compensation to enforce the duty of timeliness. ${ }^{78}$

ICSID's proposed amendments to its Arbitration Rules move in the direction of establishing an institutional duty of efficiency, particularly with the new language in arbitrators' declarations and the requirement to "use best efforts" to meet deadlines. ${ }^{79}$ However, the best-efforts requirement focuses primary attention on the parties rather than the institution: "If the Tribunal cannot comply with an applicable time limit, it shall advise the parties of the special circumstances justifying the delay and the date when it anticipates rendering the order, decision or Award." 80 Furthermore, the amendments would not create a mechanism for institutional approval of delays. Thus, whether the proposed amendments would establish an institutional duty of timely awards remains an open question. The answer depends on whether ICSID would use its enforcement powers to discipline inefficiency. ${ }^{81}$

The difference between the ICSID and ICC/SCC approaches may reflect the passage of time since the ICSID Convention entered into force in 1966. Over fifty years ago, it was probably not foreseen that delays, even when blessed by the parties, could affect the institution's reputation for rendering timely justice. Until recently, arbitration was commonly seen as fast. ${ }^{82}$ As concerns about the length and expense of arbitration have grown, however, institutions have responded with efforts to encourage efficiency. ICSID has tried within the limits of its constitutional commitment to party autonomy on procedural matters. The other institutions are free of that

77. ICC Rules, supra note 13, art. 39(1).

78. ROGERS, supra note 19, at 253 ("[R]epresentatives of the ICC have stated publicly that they have 'punished' delayed awards or other arbitrator dereliction with reduced fees."); accord LCIA Rules, supra note 14, art. 10.7 ("[Where the LCIA Court removes an arbitrator, it] shall determine the amount of fees and expenses (if any) to be paid for the former arbitrator's services, as it may consider appropriate in the circumstances."); see also ROGERS, supra note 19, at 252 ("While not usually characterized as a form of regulation, arbitral institutions' control over compensation for arbitrators' fees and costs incurred fits within modern meanings of 'regulation.'").

79. See supra notes $68-70$ and accompanying text.

80. ICSID Proposals, supra note 35, r. 12(2), at 37 (emphasis added).

81. ICSID rejected the suggestion made by several states that it replace the best-efforts requirement with a "firm obligation" to meet deadlines, on the ground that arbitrators need flexibility to address "special circumstances." Id. at 291-92. In response to the suggestion that "consequences be tied to noncompliance" with deadlines, ICSID stated: "The Centre will adopt multiple rules and practices to reinforce compliance [with deadlines] . . ." Id. at 293. Such measures will include tracking compliance with deadlines on the ICSID website, reminding arbitrators of time limits throughout the proceeding, and even postponing payment of arbitrator invoices in case of delay. Id.

82. See, e.g., Loukas A. Mistelis, Efficiency. What Else? Efficiency as the Emerging Defining Value of International Arbitration: Between Systems Theories and Party Autonomy 2 (Queen Mary Univ. of London, Sch. of Law Legal Studies Research, Paper No. 313/2019, 2019), https://ssrn.com/ abstract=3372341 [https://perma.cc/EN7S-SEB8] ("For many years, there was a presumption or perhaps a false impression that arbitration was quick and inexpensive."). 
constitutional constraint - and they are probably more motivated than ICSID to address reputational concerns about delay, because such concerns are acute in the more competitive marketplace for commercial arbitration. ${ }^{83}$

\section{B. Duty to Follow Institutional Requirements}

ICSID arbitrators must conduct arbitral proceedings "in accordance with the provisions of this Section [of the ICSID Convention] and, except as the parties otherwise agree, in accordance with the Arbitration Rules." ${ }^{\text {" }}$ This language expressly refers to the section of the ICSID Convention concerning the "powers and functions" of an arbitral tribunal. It sets an order of priority: Convention provisions are mandatory, while the Arbitration Rules generally may yield to party autonomy. In other words, arbitrators owe an inflexible duty to ICSID to comply with the Convention.

The duty to follow the ICSID Convention governs the conduct of proceedings and bests the duty arbitrators owe to respect party autonomy. Although the text explicitly refers to only one part of the Convention, the duty to comply with the Convention is broader. It would be nonsensical to suggest that ICSID tribunals may ignore other Convention provisions such as the requirement of party consent to ICSID jurisdiction, the rule that tribunals make decisions by majority vote, and the rules governing interpretation and revision of awards. The duty to follow the Convention underpins all other ICSID rules; its nature is constitutional. ${ }^{85}$

The ICC approach is similar, albeit without ICSID's two-level structure. ICC Rule 11(5) states, "By accepting to serve, arbitrators undertake to carry out their responsibilities in accordance with the Rules." Likewise, Rule 19 fixes compliance with the Rules above party autonomy in the ICC hierarchy: "The proceedings before the arbitral tribunal shall be governed by the Rules and, where the Rules are silent, by any rules which the parties or, failing them, the arbitral tribunal may settle on...." ${ }^{87}$ The

83. Cf. Suha Jubran Ballan, Investment Treaty Arbitration and Institutional Backgrounds: An Empirical Study, 34 WIS. INT'L L.J. 31, 88 (2016) (concluding that ICSID cases are significantly longer on average than SCC and UNCITRAL cases).

84. ICSID Convention, supra note 6, art. 44.

85. In this regard, this duty recalls Louis Henkin's description of the role of pacta sunt servanda in the law of treaties as "an antecedent, underlying 'constitutional' principle" on which the "normative character" of the law depends. See Louis Henkin, International Law: Politics And VAlues 28 (1995); see Vienna Convention on the Law of Treaties, art. 26, May 23, 1969, 1155 U.N.T.S. 331, 8 I.L.M. 679 [hereinafter Vienna Convention] ("Every treaty in force is binding upon the parties to it and must be performed by them in good faith.").

86. ICC Rules, supra note 13, art. 11(5).

87. Id. art. 19 (emphasis added). 
PCA, by contrast, allows parties to modify the procedures by agreement, placing party autonomy over the institutional rules. ${ }^{88}$

Confidentiality exemplifies an institution-imposed requirement. ${ }^{89}$ ICSID requires arbitrators to promise confidentiality. ${ }^{90}$ The SCC mandates that arbitrators "shall maintain the confidentiality of the arbitration and the award." These confidentiality duties are owed to both the parties and the institutions. Both have interests in assuring that arbitrators uphold the confidentiality of proceedings intended to be confidential. This is true even though the institutional interest is derivative, in that institutions suffer no harm when information is published with party consent. The SCC mandate thus expressly exempts any publication "agreed by the parties" from the duty of confidentiality. ${ }^{92}$ This sense of the subsidiary nature of the institution's interests may also be reflected in the ICC Rules. ${ }^{93}$

\section{Duty of Jurisdictional Policing ${ }^{94}$}

Article 25(1) of the ICSID Convention allows ICSID tribunals to exercise jurisdiction over certain "legal dispute[s] arising directly out of an investment." $"$ The Salini cases have found that this language creates an "investment requirement," which obliges ICSID tribunals to discern the "objective" meaning of "investment" and then assess whether the claimant

88. PCA Rules, supra note 14, art. 1(1) ("[D]isputes shall be settled in accordance with these Rules subject to such modification as the parties may agree.").

89. RESTATEMENT (THIRD) OF THE U.S. LAW OF INT'L COMMERCIAL \& INV'R-STATE ARBITRATION $\S 3.11$, Reporters' note b(iv) (AM. LAW INST., Proposed Final Draft 2019) (quoting Filip De Ly et al., International Law Association International Commercial Arbitration Committee's Report and Recommendations on 'Confidentiality in International Commercial Arbitration,' 28 ARB. INT'L 355, 373 (2012)) ("[T]here seems to be a broad consensus that the duty of confidentiality is one of the primary duties of an arbitrator....").

90. ICSID Rules, supra note 35, r. 6 ("I shall keep confidential all information coming to my knowledge as a result of my participation in this proceeding, as well as the contents of any award made by the Tribunal."); see also id. r. 15(1) ("The deliberations of the Tribunal shall take place in private and remain secret.").

91. SCC Rules, supra note 14, art. 3.

92. Id.

93. The ICC leaves to the parties' discretion whether to request confidentiality and to the tribunal's discretion how much confidentiality to order, but then compels arbitrators to honor any confidentiality order so rendered as an incident of the broader duty to follow ICC Rules. ICC Rules, supra note 13, art. 22(3). Where the institutional interests are sharper, in the case of proceedings of the ICC Court, the ICC imposes a stricter rule of confidentiality. Id. app. I, art. 6 ("The work of the Court is of a confidential nature which must be respected by everyone who participates in that work in whatever capacity.").

94. This section is adapted in part from Perry S. Bechky, Microinvestment Disputes, 45 VAND. J. TRANSNAT'L L. 1043 (2012) [hereinafter Bechky, Microinvestment Disputes]. The argument here is developed more fully in Perry S. Bechky, Salini's Nature: Arbitrators' Duty of Jurisdictional Policing, 17 J.L. \& PRAC. INT'L CTS. \& TRIBUnALS 145 (2018) [hereinafter Bechky, Salini’s Nature].

95. ICSID Convention, supra note 6, art. 25(1). 
made an investment that satisfied the tribunal's definition. ${ }^{96}$ Salini thus suggests the existence of a duty inferred from the ICSID Convention: the duty to police (at least one of) the Convention's jurisdictional limits.

The parties cannot vary the duty of jurisdictional policing. Salini declared, "it would be inaccurate to consider that the requirement that a dispute be 'in direct relation to an investment' is diluted by the consent" of the parties. $^{97}$ Salini's objective approach stands in opposition to the subjective view that a tribunal should accept the definition of "investment" used in the investment treaty that gave rise to the ICSID claim. Indeed, the Salini cases achieve their practical force precisely because they defined "investment" more narrowly than traditional investment treaties.

Salini's proponents see an important ICSID interest at stake. ${ }^{98}$ Judge Shahabuddeen, for example, framed the point starkly as "a titanic struggle between ideas, and correspondingly between capital exporting countries and capital importing ones." $" 99$ Judge Shahabuddeen argues that ICSID needs the Salini approach to preserve its distinct identity as an institution devoted to "investment disputes," lest it become "just another" arbitral institution. ${ }^{100}$ In other words, proponents justify Salini with ICSID's interest in preserving its legitimacy, which might be threatened by jurisdictional overreach. ${ }^{101}$

Furthermore, ICSID can enforce the duty of jurisdictional policing. If a tribunal fails to dismiss a claim "manifestly" lacking jurisdiction, the award

96. Salini Costruttori S.P.A. v. Kingdom of Morocco, ICSID Case No. ARB/00/4, Decision on Jurisdiction, 152 (July 16, 2001), 6 ICSID Rep. 398 (2004). Our concern here is with Salini's concept, not its details. Briefly, Salini has come to be understood as creating the following four-part "test" to define investment: "[i] contributions, [ii] a certain duration of performance of the contract and [iii] a participation in the risks of the transaction ... [and] [iv] the contribution to the economic development of the host State of the investment . . ..” Bechky, Salini's Nature, supra note 94, at 148.

97. Id.

98. I have criticized Salini on various grounds. See Bechky, Microinvestment Disputes, supra note 94. For present purposes, however, the views of Salini's proponents are what matters, as they are the ones who have created and shaped the duty of jurisdictional policing.

99. Malaysian Historical Salvors Sdn., Bhd. v. Malay., ICSID Case No. ARB/05/10, Dissenting Opinion of Judge Mohamed Shahabuddeen, I 62 (Feb. 19, 2009), http://icsidfiles.worldbank.org/ icsid/ICSIDBLOBS/OnlineAwards/C247/DC1031_En.pdf [https://perma.cc/H8A6-HAL5].

100. Id. I 63 (quoting Farouk Yala, The Notion of 'Investment' in ICSID Case Law: A Drifting Jurisdictional Requirement?, 22 J. INT’L ARB. 105, 125 (2005)).

101. In particular, Judge Shahabuddeen made an impassioned case for adhering to Salini's fourth prong: requiring a contribution to development of the host state as a jurisdictional condition. Id. $\uparrow 29$. In his view, this requirement is what "separate[s] an ICSID investment from any other kind of investment" and "ICSID arbitration ... from any other kind of arbitration ...." Id. \30. He concludes, "there could only be an ICSID investment if the investment was intended to promote the economic development of the host state ...." Id. $\mid 65$. On this view, the threat to legitimacy comes not only from mission creep in abstracto, but particularly from abandoning ICSID's “original mission" of promoting development. Id. ๆ 22. But see Bechky, Microinvestment Disputes, supra note 94, at 1064-72, 1084-93 (arguing that Salini and especially its fourth prong harm the cause of development). 
may be annulled. ${ }^{102}$ ICSID may discipline breaches of this duty, like the others discussed above, through its control over appointments. ${ }^{103}$ And there has even been one case where the absence of an investment was so plain that the ICSID Secretariat simply refused to register the claim. ${ }^{104}$

In recent years, influenced by Salini and its progeny, investment treaties narrowed the definition of "investment" by incorporating some (but almost never all) of the objective criteria listed in the cases. ${ }^{105}$ Cases under these new treaties should eventually close the gap between the subjective and objective approaches, as the Parties themselves have adopted objective elements. These new treaties show that, details aside, recent state practice has ratified the duty of tribunals to police jurisdictional limits.

\section{DUTIES TO NON-PARTY PARTICIPANTS}

Traditionally, when one state injured a citizen of another, the latter could make a state-to-state claim. The states controlled the process: they might, for example, settle the matter or submit it to some form of adjudication. ${ }^{106}$ The modern era of investment treaties has sought to "depoliticize" investment disputes by substituting the injured investor as claimant in place of its home state. ${ }^{107}$ Notwithstanding this fundamental change, it should be understood that the home state has interests in the

102. ICSID Convention, supra note 6, art. 52(1)(b) (allowing annulment if "the Tribunal has manifestly exceeded its powers ....").

103. See ROGERS, supra note 19.

104. ICSID must register arbitral claims, unless it finds that the claim is "manifestly outside the jurisdiction of the Centre." ICSID Convention, supra note 6, art. 36(3). ICSID officials have disclosed several instances where ICSID refused to register a claim, including a claim based on a "simple sale." Salini Costruttori S.P.A. v. Kingdom of Morocco, ICSID Case No. ARB/00/4, Decision on Jurisdiction, I 52 (July 16, 2001), 6 ICSID Rep. 398 (2004) (citing Ibrahim F.I. Shihata \& Antonio R. Parra, The Experience of the International Centre for Settlement of Investment Disputes, 14 FOREIGN INV. L.J. 299, 308 (1999)).

105. See, e.g., 2012 U.S. Model Bilateral Investment Treaty, art. 1 [hereinafter U.S. Model BIT], available at https://ustr.gov/sites/default/files/BIT\%20text\%20for\%20ACIEP\%20Meeting.pdf [https:// perma.cc/V6VV-8V38] (““[I]nvestment' means every asset that an investor owns or controls, directly or indirectly, that has the characteristics of an investment, including such characteristics as the commitment of capital or other resources, the expectation of gain or profit, or the assumption of risk.") (emphasis added).

106. See, e.g., Barcelona Traction, Light \& Power Co., Ltd. (Belg. v. Spain), Judgment, 1970 I.C.J. 3, 79 (Feb. 5) ("The State must be viewed as the sole judge to decide whether its protection will be granted, to what extent it is granted, and when it will cease... [T]he State enjoys complete freedom of action.").

107. See, e.g., Ibrahim F.I. Shihata, Towards a Greater Depoliticization of Investment Disputes: The Roles of ICSID and MIGA, in THE World BANK IN A CHANGING WorlD: SELECTED ESSAYS 313 (Franziska Tschofen \& Antonio R. Parra eds., 1991). 
dispute. The home state, after all, is a Party to the investment treaty, with its own reasons for entering the treaty and its own obligations thereunder. ${ }^{108}$

Other international legal regimes have long recognized that other Parties to a treaty may have interests in a dispute construing that treaty. For example, the World Trade Organization (the "WTO") has a formal procedure for "third party" participation by other Members. ${ }^{109}$ Third-party Members receive some written submissions and they have the right to make oral and written submissions to the panel and Appellate Body. ${ }^{110}$ Their submissions must be "reflected in the panel report."111 Panels must "fully take[] into account" the interests of both "the parties to a dispute and those of other Members," 112 and a study has concluded that they do so in practice. ${ }^{113}$

Investment arbitration had been somewhat slow to acknowledge the interests of the investor's home state and other non-disputing states, perhaps influenced by depoliticization and the arbitral traditions of confidentiality and party control. A marked shift in governing norms is underway, however, leaving little doubt that non-disputing state-Parties to an investment treaty now have the right to participate in arbitrations thereunder. And, where these states have rights, arbitrators owe corresponding duties.

NAFTA, a leader in opening tribunals to participation by non-disputing state-Parties, provided, "On written notice to the disputing parties, a Party may make submissions to a Tribunal on a question of interpretation of this Agreement."114 Much more recently, the UNCITRAL Rules on Transparency in Investment Treaty Arbitration state, "The arbitral tribunal shall . . . allow . . . submissions on issues of treaty interpretation from a non-

108. To minimize confusion between parties to a dispute and Parties to a treaty, this article capitalizes the latter usage.

109. Understanding on Rules and Procedures Governing the Settlement of Disputes, art. 10, Apr. 15, 1994, Marrakesh Agreement Establishing the World Trade Organization, Annex 2, 1869 U.N.T.S. 401 [hereinafter WTO DSU].

110. Id. arts. $10.2-.3,17.4$.

111. Id. art. 10.2.

112. Id. art. 10.1.

113. Sivan Shlomo Agon \& Eyal Benvenisti, The Law of Strangers: The Form and Substance of Other-Regarding International Adjudication, 68 U. TORONTO L.J. 598, 628 (2018) (“[B]oth the AB and panels have continually displayed a sympathetic other-regarding stance toward non-litigating members assuming a third party role in WTO disputes, taking their views into account in a manner shown to substantively affect the content of . . . rulings.").

114. NAFTA, supra note 3, art. 1128; accord United States-Mexico-Canada Agreement, art. 14.D.7.2, Nov. 30, 2018, https://ustr.gov/trade-agreements/free-trade-agreements/united-states-mexicocanada-agreement/agreement-between [https://perma.cc/WP6V-7TZV] ("The non-disputing Annex Party may make oral and written submissions to the tribunal regarding the interpretation of this Agreement."). 
disputing Party to the treaty." 115 This duty to "allow submissions" will extend to more cases as more states accept the Mauritius Convention concerning transparency in investment arbitration. ${ }^{116}$ The SCC adopted this approach in 2017, and ICSID has proposed to do the same. ${ }^{117}$

The duty to allow submissions should be construed generously. It must go beyond mere acceptance of a submission, to reading and respectfully considering it. Like WTO panelists, investment arbitrators should "fully take[] into account" the interests of other Parties to the treaty. ${ }^{118}$ Given that ICSID tribunals routinely construe the ICSID Convention, thereby implicating the interests of all ICSID Members, the duty to allow submissions might expand to submissions from all Member States.

On the other hand, this duty must also be properly circumscribed to respect other interests. Submissions by non-disputing Parties cannot be disruptive, unduly burdensome, or unfairly prejudicial. ${ }^{119}$ Such submissions cannot be tantamount to diplomatic protection, which is inconsistent with the nature of investor-state arbitration. ${ }^{120}$ The tribunal must not draw inferences if a home state stays silent, which again is inconsistent with the depoliticized nature of the system. ${ }^{121}$ Finally, the parties must have fair opportunity to comment on any submissions.

Arbitrators do not owe the same duty to other amici. Participation by amici other than treaty Parties is a matter of tribunal discretion, not duty, and

115. U.N. Comm'n on Int'l Trade Law, UNCITRAL Rules on Transparency in Treaty-Based Investor-State Arbitration, art. 5(1) (Jan. 2014) [hereinafter UNCITRAL Rules on Transparency], https:/uncitral.un.org/sites/uncitral.un.org/files/media-documents/uncitral/en/rules-on-transparencye.pdf [https://perma.cc/6SGG-KURK] (applying to cases conducted under the UNCITRAL Arbitration Rules).

116. United Nations Convention on Transparency in Treaty-Based Investor-State Arbitration, Annex, art. 2.1, Dec. 10, 2014, adopted by G.A. Res. 69/116 (Dec. 18, 2014) [hereinafter the Mauritius Convention] (applying the Transparency Rules to cases involving a respondent state that is party to the Mauritius Convention, whether or not the cases are governed by the UNCITRAL Arbitration Rules). The Mauritius Convention entered into force on October 18, 2017, albeit with only seven ratifications as of March 26, 2021. Status: United Nations Convention on Transparency in Treaty-Based Investor-State Arbitration (New York, 2014), UNCITRAL, https:/uncitral.un.org/en/texts/arbitration/conventions/ transparency/status [https://perma.cc/9XA9-GLE3] (last visited Mar. 26, 2021).

117. SCC Rules, supra note 14, app. III, art. 4; ICSID Proposals, supra note 35, r. 68, at 68.

118. WTO DSU, supra note 109, art. 10.1.

119. See UNCITRAL Rules on Transparency, supra note 115, art. 5(4).

120. See SCC Rules, supra note 14, app. III, art. 4(2)(ii) ("[T]he Arbitral Tribunal shall... [consider] the need to avoid submissions appearing to support the investor's claim in a manner tantamount to diplomatic protection ....").

121. See UNCITRAL Rules on Transparency, supra note 115, art. 5(3) (disallowing inferences from absence of a submission); ICSID Convention, supra note 6, art. 27 (prohibiting diplomatic protection in ICSID disputes). 
that discretion is cabined by the tribunal's other duties. ${ }^{122}$ Even so, arbitrators must owe some limited implicit duties to other amici. As the rules governing amicus participation usually specify criteria for tribunals to consider when determining whether to allow an amicus submission, ${ }^{123}$ arbitrators implicitly owe applicants the obligation to assess their applications in good faith. Likewise, where an amicus submission is accepted, arbitrators should read and respectfully consider it in good faith. ${ }^{124}$

\section{SYSTEMIC DUTIES}

A systemic duty is a duty inherent in the investor-state arbitrators' function, a duty that respects the nature and the integrity of the dispute settlement system. Systemic duties may therefore be described as "responsibilities to the process," to borrow a phrase from the NAFTA Code of Conduct, ${ }^{125}$ which has also been adopted by ICSID and UNCITRAL. ${ }^{126}$ They may arise from applicable treaties, international law, and arbitral rules.

122. See UNCITRAL Rules on Transparency, supra note 115, art. 4; ICSID Rules, supra note 35, r. 37(2); SCC Rules, supra note 14, app. III, arts. 3(8)-(10); NAFTA Free Trade Comm'n [NAFTA FTC], Statement of the Free Trade Commission on Non-Disputing Party Participation, pt. B, reprinted in 44 I.L.M. 796 (May 2005) [hereinafter Statement of NAFTA FTC].

123. See, e.g., UNCITRAL Rules on Transparency, supra note 115, art. 4(3) (“[T] he arbitral tribunal shall take into consideration, among other factors it determines to be relevant: (a) [w] hether the third person has a significant interest in the arbitral proceedings; and (b) [t]he extent to which the submission would assist the arbitral tribunal ....").

124. The NAFTA Free Trade Commission specified, "The granting of leave to file a non-disputing party submission does not require the Tribunal to address that submission at any point in the arbitration." Statement of NAFTA FTC, supra note 122, pt. B(9). While it would go too far to contend that arbitrators have a duty to address amicus submissions, I suggest they must consider the submissions lest they render the whole amicus process a charade. Moreover, it is preferable for arbitrators to address amicus submissions, as this is the only way to assure the public that the submissions were considered. $C f$. Fuller, supra note 20 ("Without [reasoned] opinions the parties have to take it on faith that . . the arbiter has in fact understood and taken into account their proofs and arguments."); Glamis Gold, Ltd. v. U.S., ICSID, Award, $₫ 8$, 48 I.L.M. 1038 (NAFTA Ch. 11 Arb. Trib. June 8, 2009) ("[I]t is the Tribunal's view that it should address those [amicus] filings explicitly in its Award to the degree they bear on decisions that must be taken.").

125. Code of Conduct for Dispute Settlement Procedures Under Chapters $19 \& 20$ of the North American Free Trade Agreement, 59 Fed. Reg. 8720, pt. I (Feb. 23, 1994) [hereinafter NAFTA Code of Conduct]. Because the NAFTA Parties "place prime importance on the integrity and impartiality" of proceedings to resolve trade disputes, they published the Code of Conduct setting forth the adjudicators' "responsibilities to the process," namely, that they "shall avoid impropriety and the appearance of impropriety and shall observe high standards of conduct so that the integrity and impartiality of the dispute settlement process is preserved." Id. pmbl., pt. I. The Code applies to adjudicators in trade disputes under NAFTA Chapters 19 and 20 - not to arbitrators in investment disputes under Chapter 11—but in my judgment, at least, there is no distinction among the dispute settlement provisions that would support a lesser regard for responsibilities to the process by investment arbitrators than trade adjudicators. Id. pmbl.

126. Draft Code, supra note 43, art. 3, para. 25 ("The enumerated duties are owed to the parties, to the process and to the other adjudicators.") (emphasis added). 
Arbitrators owe these duties, not to the parties or arbitral institutions, but to the creators of the investment arbitration system (states) and its ultimate beneficiaries (the global public). ${ }^{127}$

The Glamis Gold tribunal recognized the concept of a systemic duty, reasoning that each NAFTA tribunal must act with "sensitivity to the position of future tribunals and an awareness of other systemic implications." 128 The tribunal described NAFTA Chapter 11 as establishing "a significant public system of private investment protection," the "ultimate integrity" of which depends on each tribunal acting with "a modicum of awareness of each of these tribunals for each other and the system as a whole." $" 129$

The UNCITRAL Transparency Rules and, by extension, the Mauritius Convention on transparency in investment arbitration provide examples of systemic duties. They create certain limited duties that arbitrators owe to "any person." They divide arbitral documents into three categories:

(1) arbitrators must "ma[ke] available to the public" many documents, including pleadings, memorials, transcripts, and the tribunal's decisions;

(2) arbitrators must release "expert reports and witness statements, exclusive of the exhibits thereto" on request by "any person"; and

(3) arbitrators may release in their discretion the exhibits (and any other documents not covered by the first two categories), on their own initiative or on request by "any person," after consultation with the parties. ${ }^{130}$

The Transparency Rules thus expressly oblige arbitrators to release certain documents to "any person" and also implicitly require them to consider in good faith a request by "any person" for other documents. ${ }^{131}$ In these limited respects, therefore, arbitrators have a duty to the public.

This idea of a duty to the public can also be seen in the requirement that arbitrators make many basic documents "available to the public" without waiting for any request. ${ }^{132}$ This requirement acknowledges the public interest in transparency of investor-state arbitration and it serves that interest by placing a corresponding obligation upon arbitrators. Parties cannot waive or vary this duty owed to the public. Instead, unlike commercial arbitration,

127. Cf. Evan J. Criddle \& Evan Fox-Decent, A Fiduciary Theory of Jus Cogens, 34 YALE J. INT'L L. 331, 347 (2009) (arguing that a state's claim to sovereignty depends on fulfilling its obligations as a fiduciary of the people).

128. Glamis Gold, Ltd., 48 I.L.M. 1038, ๆ 6.

129. Id. $₫ 5$.

130. UNCITRAL Rules on Transparency, supra note 115, art. 3.

131. Id.

132. Id. 
transparency has emerged as a systemic element of investment arbitration. Consequently, investment arbitrators have systemic obligations to assure that transparency.

The fact that systemic duties are due to the public, not to a readily identifiable individual, does not render them unenforceable. Arbitral institutions may enforce systemic duties, just as they enforce institutional duties. $^{133}$ States, appointing authorities, and reviewing courts also have enforcement capabilities. And an arbitrator who breaches a systemic duty may suffer reputational discipline.

The remainder of this section discusses several systemic duties binding on investment arbitrators: (a) the duty to comply with jus cogens norms; (b) the duty to respect the United Nations Charter; and (c) certain institutional duties that also have systemic consequences.

\section{A. Duty to Comply with Jus Cogens Norms}

Investor-state arbitrators have a systemic duty to comply with jus cogens norms. A jus cogens norm is peremptory, "a norm accepted and recognized by the international community of States as a whole as a norm from which no derogation is permitted . . .."134 A treaty is void if it violates a jus cogens norm. ${ }^{135}$ It follows that investor-state arbitrators must not order any state to transgress, or penalize a state for taking actions necessary to comply with, a jus cogens norm. ${ }^{136}$ As stated by the tribunal in Methanex, "[A]s a matter of international constitutional law a tribunal has an independent duty to apply imperative principles of law or jus cogens and not to give effect to parties' choices of law that are inconsistent with such

133. The Draft Code mainly keeps its powder dry on the question of how the Code might be enforced beyond self-compliance by adjudicators and the existing disqualification and removal procedures. See Draft Code, supra note 43, art. 12. It rightly notes that attention should be paid to how enforcement is implemented, especially as there may be reputational or financial consequences for adjudicators alleged to have breached the Code. Id. art. 12, paras. 92-94. It also recognizes that enforcement options will vary depending on how ISDS evolves, e.g., whether a new court or other standing mechanism is created. Id. art. 12.3, paras. 88, 95-96. As it appears that institutions will have a role in any enforcement mechanism, the final version of the code should expressly state that arbitrators owe their duties to institutions (among the others already listed).

134. Vienna Convention, supra note 85, art. 53.

135. Id. arts. 53, 64 .

136. See, e.g., Susan L. Karamanian, The Place of Human Rights in Investor-State Arbitration, 17 LEWIS \& CLARK L.R. 423, 436 (2013) ("[J]us cogens norms should trump obligations under an [investment treaty]... ."); Moshe Hirsch, Interactions Between Investment and Non-Investment Obligations in International Investment Law 7 (Int'l Law Forum of the Hebrew Univ. of Jerusalem Faculty of Law, Research Paper No. 14-06, 2006) ("Since some fundamental human rights are protected by peremptory rules of international law ... recognizing the superior status of these rules may require future investment tribunals to subject some provisions included in investment treaties to these higher principles of public international law ...."). 
principles."137 This is a crucial systemic point to establish: investor-state arbitrators must respect the hierarchy of norms established in international law, because they act under international law $^{138}$ and their work is inextricably bound with the international legal system. ${ }^{139}$

The duty to comply with jus cogens norms retains its systemic significance, even if one might wonder how often investment arbitration impinges on such norms. As Georges Abi-Saab has said, even if the concept of jus cogens were an "empty box, the category [is] still useful; for without the box, it cannot be filled."

Determining how to fill the jus cogens box is notably challenging. The International Court of Justice has had little to say about the box's contents. ${ }^{141}$ The Court has described the prohibition of genocide as "assuredly" peremptory, ${ }^{142}$ but has otherwise spoken inconclusively. ${ }^{143}$ Even the International Law Commission decided, in its ongoing project on jus cogens,

137. Methanex Corp. v. U.S., Final Award, pt. IV, ch. C, ๆ 24 (Aug. 3, 2005) 16 ICSID Rep. 32 (2005) (rejecting the contention that the United States had violated a jus cogens norm against nondiscrimination, while accepting that some actions inhibiting claims against discrimination could rise to the level of jus cogens violations).

138. At least in the context of tribunals in investment treaty cases and other ICSID tribunals, perhaps leaving some room to quibble about investor-state arbitration in cases outside ICSID arising from contracts or domestic law.

139. In this regard, Pauwelyn notes:

$[S]$ tates, in their treaty relations, can contract out of . . rules of general international law (other than those of jus cogens), but they cannot contract out of the system of international law. As soon as States contract with one another, they do so automatically and necessarily within the system of international law.

Joost Pauwelyn, The Role of Public International Law in the WTO: How Far Can We Go?, 95 AM. J. INT'L L. 535, 539 (2001). An ICSID award deemed it "evident" that Pauwelyn's logic "holds true in international investment law" as well. Phoenix Action, Ltd. v. Czech, ICSID Case No. ARB/06/5, Award, I 78 (Apr. 15, 2009), http://icsidfiles.worldbank.org/icsid/ICSIDBLOBS/OnlineAwards/C74/DC1033 En.pdf [https://perma.cc/5L3K-HNGS].

140. Strong, supra note 52, at 391, 391 n.242 (quoting Georges Abi-Saab, The Third World and the Future of the International Legal Order, 29 REVUE EGYPTIENNE DE DROIT INT'L 27, 53 (1973)) (Egypt) (internal punctuation omitted).

141. See Vienna Convention, supra note 85, art. 53.

142. Armed Activities on the Territory of the Congo (Dem. Rep. Congo v. Rwanda), Judgment, 2006 I.C.J. 6, ๆ 64 (July 6).

143. For example, in Nicaragua v. United States, the Court noted that the International Law Commission and the state parties considered the prohibition on use of armed force to be jus cogens, without announcing its own conclusion. Military and Paramilitary Activities in and Against Nicaragua (Nicar. v. U.S.), Judgment, 1986 I.C.J. 14, ๆ 190 (June 27). Likewise, in Germany v. Italy, the Court assumed without deciding "that the rules of the law of armed conflict which prohibit the murder of civilians in occupied territory, the deportation of civilian inhabitants to slave labour and the deportation of prisoners of war to slave labour are rules of jus cogens . . .." Jurisdictional Immunities of the State (Ger. v. It.), Judgment, 2012 I.C.J. 100, ๆ 93 (Feb. 3). 
not to "provide an illustrative list of existing norms of jus cogens."144 This uncertainty may well put investment arbitrators in the difficult - frankly unsettling - position of having to decide whether certain norms rise to the jus cogens level with little guidance from the Court or Commission. Although this duty is heavy, it must not be shirked in an appropriate case. The alternative would risk grave harm to the public interest by, for example, finding a state in breach of a treaty that is void precisely because it conflicts with the highest values of the international community.

The impact of peremptory norms on investment arbitration (and vice versa) depends on how the jus cogens box is filled. We may hope and expect that few claims will ever be brought concerning "investments made in violation of the most fundamental rules of protection of human rights, like investments made in pursuance of torture or genocide or in support of slavery or trafficking of human organs." "145 But broader conceptions of jus cogens could overlap more frequently, and more profoundly, with investment arbitration. For example, Professor Sornarajah has argued that "permanent sovereignty over natural resources" is a jus cogens norm that prioritizes the public interest over contracts concerning natural resources by "justif[ying] variations of these contractual rights when the public interest requires such a change."146 Perhaps even more broadly, Sornarajah has contended that investment treaty protection should be cast aside during times of "economic and political crisis."147 He posits that the investment treaty's "lesser . . . obligations" should yield to the state's "duty to restore order," which serves the right to life and "some social and economic rights [that] are also ius cogens rights." $" 148$

Beyond the challenge of determining which norms qualify as jus cogens, investment arbitrators may also face other difficult questions about

144. See Sean D. Murphy, Peremptory Norms of General International Law (Jus Cogens) and Other Topics: The Seventy-First Session of the International Law Commission, 114 AM. J. INT'L L. 68, 71-72 (2020). Concerned that the task of "determining whether a particular norm is jus cogens is ... very complex and, at times, controversial," the Commission instead published "a list of some of the norms that have been 'referred to' in prior work ... without assessing whether those norms . . are jus cogens ...." Id. The Commission's list has only eight norms, concerning aggression, genocide, crimes against humanity, international humanitarian law, racial discrimination, slavery, torture, and self-determination. Id. at 71. For an example of a much longer list of candidates, see THOMAS WEATHERALL, JUS COGENS: INTERNATIONAL LAW AND SOCIAL CONTRACT 200-65 (2015).

145. Phoenix Action, Ltd. v. Czech, ICSID Case No. ARB/06/5, Award, ๆ 78 (Apr. 15, 2009), http://icsidfiles.worldbank.org/icsid/ICSIDBLOBS/OnlineAwards/C74/DC1033_En.pdf [https://perma .cc/58A2-HXWT] (deeming such investments beyond the pale of ICSID jurisdiction).

146. El Paso Energy Int'1 Co. v. Arg., ICSID Case No. ARB/03/15, Legal Opinion of M. Sornarajah, I 28 (Mar. 5, 2007), https://www.italaw.com/sites/default/files/case-documents/ita0970.pdf [https:// perma.cc/XC8P-KERA]; see also id. $1 \uparrow 1$ 125-26.

147. Id. ๆๆ 123-24.

148. Id. 
the impact of peremptory norms on actual cases. For example, can jus cogens be raised as a sword or only as a shield? ${ }^{149}$ How closely must the government actions at issue relate to the jus cogens norms they claim to serve, does it matter whether the state could have pursued an alternative policy less harmful to the investor, and how much leeway do governments have in choosing whether, when, and how to act ${ }^{150}$

\section{B. Duty to Respect the United Nations Charter}

Article 103 of the UN Charter provides, "In the event of a conflict between the obligations of the Members of the United Nations under the present Charter and their obligations under any other international agreement, their obligations under the present Charter shall prevail."151 Article 103 raises issues akin to jus cogens by elevating certain legal obligations above investment treaties. Investment arbitrators act as part of the international legal system and thus owe the systemic duty to give priority to states' Charter obligations over investment treaties in case of a conflict.

Such conflicts might arise from economic sanctions imposed by the UN Security Council to "maintain or restore international peace and security."152 The Security Council has the power to decide what measures to take, including "complete or partial interruption of economic relations," and to "call upon the Members of the United Nations to apply such measures." 153 "[A]ll the Members of the United Nations" must take "the action required to carry out the decisions of the Security Council." 154

For example, in September 2017 in response to North Korea's nuclear program, the Security Council decided that "States shall prohibit, by their nationals or in their territories, the opening, maintenance, and operation of all joint ventures or cooperative entities, new and existing, with [North

149. See Karamanian, supra note 136, at 435-38 (favoring defensive, over offensive, invocations of jus cogens).

150. These difficulties recall past controversies in international investment law about the meaning of the word "necessary" and margins of appreciation. Compare William W. Burke-White \& Andreas von Staden, Investment Protection in Extraordinary Times: The Interpretation and Application of NonPrecluded Measures Provisions in Bilateral Investment Treaties, 48 VA. J. INT'L L. 307, 409 (2008) (arguing for more deference to states in the interpretation of clauses that allow measures "necessary" for certain public interests, based on the European margin of appreciation doctrine and the least restrictive alternative approach in WTO cases), with José E. Alvarez \& Tegan Brink, Revisiting the Necessity Defense: Continental Casualty v. Argentina, in YEARBOOK ON INTERNATIONAL INVESTMENT LAW AND POLICY 2010-2011 319, 352 (Karl P. Sauvant ed., 2012) (arguing for an approach to such clauses based on the narrower definition of "necessity" used in customary international law).

151. U.N. Charter art. 103.

152. Id. art. 39.

153. Id. art. 41.

154. Id. art. $48, \uparrow 1$. 
Korean] entities or individuals." ${ }^{155}$ The potential impact on investors is plain. If a North Korean investor, hurt by Chinese sanctions taken pursuant to the Security Council Resolution, were to bring an arbitral claim under the China-North Korea investment treaty, China should have a valid defense under Article 103. ${ }^{156}$ Some investment treaties take the precaution of expressly listing compliance with Security Council Resolutions as a defense, ${ }^{157}$ but such language is not strictly necessary in light of Article 103.

The pool of potential claimants is not restricted to North Korean investors. For example, if the joint venture in China shuttered by sanctions had a Swiss joint venture partner, the Swiss partner would also have a claim regarding the Chinese actions against the joint venture but for Article 103. ${ }^{158}$ Likewise for a German investor in China ${ }^{159}$ whose business depended on importing North Korean lead, but was crippled by another aspect of the UN sanctions. ${ }^{160}$

\section{Institutional Duties Revisited}

As discussed, investor-state arbitrators owe duties to arbitral institutions, including the duty to judge fairly, the duty of independence and impartiality, the duty of diligence, the duty to give reasons, the duty to follow institutional requirements, and the duty of jurisdictional policing. ${ }^{161}$ Having

155. S.C. Res. 2375, ๆ 18 (Sept. 11, 2017). The Security Council excepted, significantly, "existing China-DPRK hydroelectric power infrastructure projects and the Russia-DPRK Rajin-Khasan port and rail project" as well as projects approved in advance by a UN Committee, "in particular ... noncommercial, public utility infrastructure projects not generating profit . . . ." Id.

156. Agreement on the Promotion and Protection of Investments, China-N. Kor., art. 9(3), Mar. 22, 2005, https://investmentpolicy.unctad.org/international-investment-agreements/treaty-files/750/down load [https://perma.cc/N2GP-KNEN] (last visited Mar. 28, 2021) (allowing ad hoc arbitration). Even isolated, communist North Korea has fifteen investment treaties in force. IIAs By Economy: Korea, Dem. People's Rep. of: Bilateral Investment Treaties (BITs), INV. POL'Y HuB, https://investmentpolicy. unctad.org/international-investment-agreements/countries/110/korea-democratic-people-s-republic-of [https://perma.cc/7U62-N4QX ] (last visited Mar. 28, 2021) (listing the bilateral investment treaties between North Korea and various countries).

157. See, e.g., Agreement for the Promotion, Facilitation, and Protection of Investment, ChinaJapan-S. Kor., art. 18(1)(b), May 13, 2012, https://investmentpolicy.unctad.org/international-investmentagreements/treaty-files/2633/download [https://perma.cc/PZK2-7H6V]. More commonly, treaty defenses refer to "maintenance or restoration of international peace and security," tracking the Charter's language without naming it. See, e.g., U.S. Model BIT, supra note 105, art. 18(2).

158. Agreement on the Promotion and Reciprocal Protection of Investments, China-Switz., art. 11, Jan. 27, 2009, https://investmentpolicy.unctad.org/international-investment-agreements/treaty-files/ 4811/download [https://perma.cc/AZ68-C3N7].

159. Agreement on the Encouragement and Reciprocal Protection of Investments, China-Ger., art. 9, Dec. 1, 2003, 2362 U.N.T.S. 253.

160. S.C. Res. 2371, ๆ 10 (Aug. 5, 2017).

161. See supra Parts II-III. 
explained why these duties are owed to the institutions, I now reconsider the same duties from a systemic perspective.

Picture an ICSID arbitration. Now, remove ICSID from the image. Should the arbitrators hearing the same case ad hoc behave differently because the case is outside ICSID? In some respects, the answer is yes: the Convention does not apply, the arbitral rules differ. But the arbitrators' fundamental responsibilities as arbitrators remain the same. The arbitrators must remain impartial and independent. They must conduct fair proceedings. They must produce timely, written, valid, enforceable, and usually reasoned awards. ${ }^{162}$

Removing the institution from the picture highlights that many institutional duties are also systemic. They are inherent in the investment arbitration system. ${ }^{163}$ They are necessary to the basic legitimacy of the system. They serve the public interest. Like other systemic duties, they may be enforced by appointing authorities and reviewing courts, as well as by parties and institutions.

The way Salini's duty of jurisdictional policing slipped loose the bounds of ICSID illustrates this relationship between institutional and systemic duties. Given that Salini construes a provision of the ICSID Convention, one might have expected its duty to remain within ICSID's confines. As discussed above, however, recent investment treaties tend to incorporate aspects of Salini's test into their definitions - a trend that should oblige non-ICSID tribunals to similarly police jurisdictional limits. Indeed, Salini's movement beyond ICSID has already begun. At least two tribunals acting outside the ICSID Convention have applied Salini's duty, both considering that this duty should apply equally regardless of the arbitral forum because they deemed it inherent in the concept of investment arbitration. ${ }^{164}$ What began as an institutional duty-based on particular

162. One might contend that these duties are not truly systemic, because the arbitrators are merely following the applicable arbitral rules. This contention is valid to some extent, but it misses the larger point that all the arbitral rules mandate compliance with this same set of responsibilities precisely because they are so central to the investment arbitrators' function. It is almost inconceivable that one of the major international institutions would permit arbitrators to deviate from such basic norms. Were an institution to do so, states should object and refuse to consent to arbitration there. Admittedly, renegotiating investment treaties to remove previously-agreed consent clauses is challenging, which would be more concerning were this scenario less far-fetched.

163. In this regard, ICSID and UNCITRAL have jointly proposed a draft code of conduct to apply to all investor-state disputes. See Draft Code, supra note 43. The trans-institutional nature of the proposal supports the view that the adjudicators' responsibilities are systemic in nature. Unsurprisingly, the Draft Code incorporates all of the fundamental responsibilities discussed in this article, including fairness, diligence, and independence and impartiality. Id. arts. 3-4, 7.1, 8.1.

164. Romak S.A. v. Uzb., PCA Case Repository No. AA280, Award, qๆ 207-08 (Nov. 26, 2009), https://pcacases.com/web/sendAttach/491 [https://perma.cc/6ABJ-H3NJ]; Nova Scotia Power Inc. v. 
language in the ICSID Convention and particular institutional considerations - came to be seen by states and tribunals as a duty that should be applied, with some changes, system-wide.

Glamis Gold expressly used systemic duties to inform its approach to the duty to give reasons. ${ }^{165}$ The tribunal considered it "important that a NAFTA tribunal provide particularly detailed reasons for its decisions," to foster "governmental and public faith in the integrity of the process of arbitration" and long-term support for the NAFTA system. ${ }^{166}$ Glamis Gold also considered that the nature of the NAFTA arbitration system required it to include in its award both an executive summary that "communicate[s] its conclusions succinctly to the various branches of government or public" and

Venez., ICSID Case No. ARB(AF)/11/1, Award, ๆ甲 75, 78, 80-81, 84 (Apr. 30, 2014), http://icsidfiles. worldbank.org/icsid/ICSIDBLOBS/OnlineAwards/C1380/DC4774_En.pdf [https://perma.cc/7UF9-SA F8]. Note that cases heard by the ICSID Additional Facility are not governed by the ICSID Convention. For an introduction to the Additional Facility, see SCHREUER ET AL., supra note 10, at 141-43, 1120-23.

165. Glamis Gold was governed by the UNCITRAL Arbitration Rules, which require written awards, normally with reasons unless the parties agree otherwise. See Glamis Gold, Ltd. v. U.S., ICSID, Award, ๆ 8, 48 I.L.M. 1038 (NAFTA Ch. 11 Arb. Trib. June 8, 2009); see UNCITRAL Arbitration Rules, supra note 27 , arts. 34(2)-(3). We have seen above the private benefits of reasoned awards, but such awards also serve the public interest, at least when published. See supra note 20 and accompanying text. The ICSID Convention prioritizes party autonomy over the public interest with regard to publication, specifying that awards may only be published with party consent. ICSID Convention, supra 6, art. 48(5). In practice, however, many ICSID awards have become public and ICSID has gone so far as to commit to publish "excerpts of legal reasoning" even without party consent. ICSID Rules, supra note 35, r. 48(4); see also Int'l Ctr. for Settlement of Inv. Disputes [ICSID], ICSID Administrative and Financial Regulations, ch. IV, Reg. 22(2) (Apr. 10, 2006) ("The Secretary-General shall ... . arrange for ... publication... with a view to furthering the development of international law in relation to investments."). Publication has helped to build the law, described variously as "[a] consolidating jurisprudence, an international common law of investor rights, an investment jurisprudence, or a common legal opinion or jurisprudence constante" and even "ICSID's case law." Jeffery P. Commission, Precedent in Investment Treaty Arbitration, 24 J. INT'L ARB. 129, 135, 144 (2007) (internal quotation marks omitted); see also Andrea K. Bjorklund, Investment Treaty Arbitral Decisions as Jurisprudence Constante, in InTERnAtional ECONOMic LAw: THE STATE AND FUTURE OF THE Discipline 265, 274 (Colin B. Picker et al. eds., 2008) (arguing that investor-state precedents will produce a jurisprudence constante, akin to civil law societies, capable of producing "significant advantages with respect to predictability and legitimacy ....").

166. Glamis Gold, Ltd., 48 I.L.M. 1038, ๆ 8; accord Federico Ortino, Transparency of Investment Awards: External and Internal Dimensions, in TRANSPARENCY IN INTERNATIONAL TRADE AND INVESTMENT DiSPUTE SETTLEMENT 119, 138-40 (Junji Nakagawa ed., 2013) (calling for arbitrators to provide "a high level of clarity in their reasoning" given the nature of "investment treaty disputes [as] essentially a form of public law adjudication.”); Benedict Kingsbury \& Stephan Schill, Investor-State Arbitration as Governance: Fair and Equitable Treatment, Proportionality and the Emerging Global Administrative Law 45 (N.Y. UNIV. Sch. of Law Inst. for Int'l Law \& Justice, IILJ Working Paper No. 2009/6, 2009) (arguing that the reasoning of awards should speak to the "interests and engagements of non-represented and non-participating stakeholders" and, where appropriate, "should engage with these wider and systemic issues"). 
an explanation of any departure from "major trends present in previous decisions." 167

Traco $v$. Poland offers a third example of a dual institutional-systemic duty. The case arose from the investment treaty between Germany and Poland, which specified that each party "shall bear the cost of its own member" on the tribunal, unless the "tribunal may make a different regulation concerning costs." 168 The ad hoc tribunal decided to require the parties to share the fees of all three arbitrators, finding the notion that each party has "its own member" is:

based on a misconception of arbitral justice that the Tribunal considers manifestly incompatible with contemporary conceptions of the independence and impartiality of international arbitrators. ... [T] he same standard of impartiality and independence is required for all members of an arbitration tribunal; and an arbitrator cannot be considered, by virtue of his or her appointment by one disputing party, to be that party's 'own' arbitrator. In this case, all three arbitrators were and remain required to be arbitrators for both Parties, with the two party-appointed arbitrators under exactly the same duties of independence and impartiality as the chairman. $^{169}$

The Traco tribunal thus recognized a systemic interest in arbitrators' independence and impartiality and invoked that interest to guide its discretion in allocating costs. ${ }^{170}$

167. Glamis Gold, Ltd., 48 I.L.M. 1038, ๆ 8.

168. Treaty Concerning the Encouragement and Reciprocal Protection of Investments, Ger.-Pol., art. 10(5), Nov. 10, 1989, 1708 U.N.T.S. 324 (emphasis added).

169. Luke Eric Peterson, Citing Need for Independence and Impartiality of All Arbitrators, Tribunal Frowns on BIT's Provision that Each Party Should Fund Its Own Arbitrator; Similar BIT Wording Led to Unpublicized Reversal of Costs Ruling in Eureko v. Poland Case, INV. ARB. REP. (Feb. 19, 2019), https://www.iareporter.com/articles/citing-need-for-independence-and-impartiality-of-all-arbitratorstribunal-frowns-on-bits-provision-that-each-party-should-fund-its-own-arbitrator-similar-bit-wordingled-to-unpublicized-reversal-o/ [https://perma.cc/M7NN-Y42X] (quoting TRACO Deutsche Travertin Werke GmbH v. Pol., Final Award on Costs (Perm. Ct. Arb. 2013) (not published)).

170. Investment Arbitration Reporter also reports on two similar cases that seem to show a limit to the Traco approach. Id. These cases arose under the Netherlands-Poland investment treaty, which similarly provides for each party to bear the costs of the "arbitrator appointed by itself" without any language empowering the tribunal to divide costs differently. Id. Enkev v. Poland decided that the treaty language "circumscribed" the tribunal's powers to allocate costs, while Eureko v. Poland apparently went so far as to reverse a cost decision that had failed to comply with the treaty rule on costs. Id.; Enkev Beheer B.V. v. Pol., PCA Case No. 2013-01, Final Award on Costs, I 57 (June 13, 2014), https:// www.italaw.com/sites/default/files/case-documents/italaw6209.pdf [https://perma.cc/73J4-EH9G]. In other words, in these cases, the systemic interest in preserving arbitrators' independence and impartiality from erosion by outdated notions of arbitrator compensation yielded to the tribunal's duty to follow the applicable law. 
By contrast, arbitrators' duty of confidentiality is mainly institutional, without a systemic counterpart. ${ }^{171}$ Institutions impose varying duties of confidentiality - or none. There is generally no public interest in insisting on stricter confidentiality than the institutions themselves require. In fact, the public interest normally runs the other way: an interest in securing access to information of public concern. ${ }^{172}$ This is the public interest captured in the UNCITRAL Rules on Transparency, the Mauritius Convention, and the ICSID Rules. ${ }^{173}$ Arguably, however, there is a systemic duty to maintain confidentiality of two types of information: arbitrators' private deliberations ${ }^{174}$ and particularly sensitive information (such as trade secrets and classified information) that must be disclosed to an investor-state tribunal. Such sensitive information is properly excepted from public disclosure. ${ }^{175}$ This exception serves the basic legitimacy of the investment arbitration system as any adjudicator must allow parties to present their cases, ${ }^{176}$ a necessity that should not be inhibited by threat of public revelation of this core minimum of sensitive information.

\section{WHY DUTIES TO NON-PARTIES MATTER}

Benedict Kingsbury and his co-authors define "global administrative law" as:

comprising the mechanisms, principles, practices, and supporting social understandings that promote or otherwise affect the accountability of global administrative bodies, in particular by ensuring they meet adequate

171. See supra notes 89-93 and accompanying text; RESTATEMENT (THIRD) OF THE U.S. LAW OF INT'L COMMERCIAL \& INV'R-STATE ARBITRATION $§ 3.11$, Reporters' note b(iv) (AM. LAW InST., Proposed Final Draft 2019).

172. Cf. Jeswald W. Salacuse, The Emerging Global Regime for Investment, 51 HARV. INT'L L.J. 427,462 (2010) ("[C]onfidentiality ... would seem to weaken the role of investor-state arbitration as a mechanism for regime decisionmaking. Regime decisions need to be widely and publicly diffused for the regime to operate effectively.").

173. See supra Part IV.

174. See, e.g., Katia Fach GÓmEZ, Key Duties of INTERnAtional INVESTMENT ARbitrators: A Transnational Study of Legal AND Ethical Dilemmas 173 (2019) (arguing that the confidentiality of deliberations works in tandem with duties of transparency to serve the legitimacy of investment arbitration). One could make the case that this duty is also owed to the other arbitrators on the tribunal, who might be able to enforce it through social sanctions (like speaking invitations) or even through their role in making appointments in other cases where they act as counsel or appointing authority. See, e.g., Draft Code, supra note 43, arts. 3, para. 25, 9.1(c).

175. See UNCITRAL Rules on Transparency, supra note 115, art. 7; see also ICSID Proposals, supra note 35, r. 66, at 66-67 (listing ten types of information exempt from public disclosure).

176. Cf. UNCITRAL MODEL LAW, supra note 14, art. 18 ("[E]ach party shall be given a full opportunity of presenting his case.”); RESTATEMENT (THIRD) OF THE U.S. LAW OF INT'L COMMERCIAL \& INV'R-STATE ARBITRATION $\S 4.18 \mathrm{cmt}$. a (“An essential feature of adjudication is that the parties be able to present their claims to, and have them assessed by, an impartial decisionmaker."). 
standards of transparency, participation, reasoned decision, and legality, and by providing effective review of the rules and decisions they make. ${ }^{17\}}$

They describe a "multifaceted 'global administrative space"" populated by a wide variety of "global administrative bodies" - public, private, and hybrid, formal and informal-with a range of functions, including certain adjudications. $^{178}$

Just as Kingsbury identified transparency and participation as core concerns of global administrative law, subsequent literature has stressed a trend towards greater respect for the interests of outsiders affected by the rules. Eyal Benvenisti calls this respect "other-regardingness."179 Ayelet Berman, for example, has discussed the OECD's recommendations that states should "give consideration" to the impact their regulations will have on foreign interests and "ensure" that their rulemaking processes "provide opportunities for consultation with external partners."180 Likewise, a study of WTO disputes concludes by emphasizing the organization's commitment to other-regardingness:

WTO adjudicators act not simply as agents of contracting states but, rather, as trustees of the overarching WTO regime, considering not only the bilateral relationship between the disputing states but also the collective interests related to the wider community of states of which the disputants form a part. Moreover, not infrequently, though not always explicitly, the adjudicators go further to consider broader community interests and global concerns, thereby acting in various ways as trustees of humanity. ${ }^{181}$

Recognizing that investment arbitrators have duties to non-parties dovetails with this trend towards other-regardingness in global administrative law. Investment arbitrators may be seen as rule-makers, acting with the authority delegated to them through a system created by

177. Benedict Kingsbury et al., The Emergence of Global Administrative Law, 68 LAW \& CONTEMP. PROBS. 15, 17 (2005).

178. Id. at 17 n. 4,18 .

179. Eyal Benvenisti, Sovereigns as Trustees of Humanity: On the Accountability of States to Foreign Stakeholders, 107 AM. J. INT’L L. 295, 300 (2013) (internal punctuation omitted).

180. Ayelet Berman, Taking Foreign Interests into Account: Rulemaking in the US and EU, 15 INT'L J. CONST. L. 235, 254 (2017) (quoting Org. for Econ. Co-operation \& Dev. [OECD], Recommendation of the Council on Regulatory Policy and Governance, at 31 (Mar. 22, 2012), http:// www.oecd.org/gov/regulatory-policy/49990817.pdf [https://perma.cc/6LR6-4LNB]). Berman observes that "enlightened self-interest" mainly drives regulators to take outsiders' interests into account. Id. Given the crisis facing investment arbitration, it might be suggested that arbitrators' enlightened self-interest impels them in the same direction.

181. Agon \& Benvenisti, supra note 113, at 659-60. It seems that the authors are not yet prepared to extend the same principle of other-regardingness to investment arbitration, not even normatively, suggesting that "a more fruitful ground" for that development "would be established" after the Investment Court under the Canada-EU Comprehensive Economic and Trade Agreement ("CETA") starts operating. Id. at 658 . 
states, whose decisions help regulate state conduct. As such, they are part of a public system of governance. ${ }^{182}$ Recognizing that arbitrators have responsibilities to non-parties contributes to building governance systems that appropriately respect the interests of all affected persons.

Other-regardingness explains why party autonomy, while vital, is not the supreme value of the investment arbitration system. The system must work well for parties, but it also must work well for non-party stakeholders such as the institutions that host cases, the states that create and support the system, and ultimately the public those states serve. Sometimes otherregarding concerns weigh heavily enough to warrant curbing party autonomy.

Perhaps it is most important that arbitrators themselves recognize their responsibility to give due respect to non-party interests. This recognition could affect how arbitrators conceive and approach their job. It could affect the questions they ask, the procedures they follow, the answers they reach. If arbitrators "deal in virtue," acts and judgments. HEP exemplified this possibility, by prioritizing the legitimacy of the process over a party's freedom to hire the counsel of its choice. $^{184}$

Recognition of non-party interests could also affect how arbitral institutions act to protect their interests, as well as systemic interests. We have already seen duties that institutions create and enforce. ${ }^{185}$ Recognition that such duties do and should exist may help consolidate and advance this trend. New duties might emerge, especially when institutions update their rules, and existing duties might be enforced more openly and rigorously. Forthright recognition could affect the ongoing debate about the appropriate scope of arbitrator immunity, perhaps leading the ICC to constrain immunity as the LCIA and SCC have done. ${ }^{186}$ Institutions should not hesitate to make clear their core minimum expectations for arbitrators and the consequences

182. Kingsbury et al. mention investment arbitration, implying it is part of the global administrative space, a point made explicitly by Kingsbury's later work with Schill. Kingsbury et al., supra note 177, at 36, 47; Kingsbury \& Schill, supra note 166, at 1; accord Harold Hongju Koh, Transnational Public Law Litigation, 100 YALE L.J. 2347, 2360 n.71, 2401 n.283 (1991) (describing investor-state arbitration as a form of transnational public law litigation).

183. See generally DEZALAY \& GARTH, supra note 33 and accompanying text.

184. See supra notes 57-64 and accompanying text.

185. See supra Parts II-III.

186. Compare ICC Rules, supra note 13, art. 41 (affording arbitrator immunity except as "prohibited by applicable law"), with LCIA Rules, supra note 14, art. 31.1 (barring arbitrator liability from extending to parties except when there is evidence of "conscious and deliberate wrongdoing"), and SCC Rules, supra note 14, art. 52 (barring a finding of arbitrator liability except for acts or omissions attributable to "wilful misconduct or gross negligence"). 
of breach. And they should take those expectations into account when appointing arbitrators.

Similarly, increasing recognition of arbitrators' duties to non-parties might affect state behavior. States might incorporate arbitrator codes of conduct in their investment treaties and in their standards and practices for making appointments to tribunals and institutional rosters. ${ }^{187}$ They might also participate more actively as non-disputing Parties in investment cases, as has been the practice with WTO third-party submissions, ${ }^{188}$ and encourage tribunals to give due respect to non-party submissions by other amici.

Academics, practitioners, and civil society have a role, too, in shaping the norms and expectations for investment arbitrators. For example, individuals and NGO's are able to participate in ICSID's and UNCITRAL's project to prepare a code of conduct for investor-state disputes. ${ }^{189}$ They may also exert influence through their own work, such as the ALI's Restatement, ${ }^{190}$ the IBA's Rules of Ethics for International Arbitrators, ${ }^{191}$ and Catherine Rogers' scholarship on ethics. ${ }^{192}$

187. See Chiara Giorgetti \& Jeffrey L. Dunoff, Ex Pluribus Unum? On the Form and Shape of a Common Code of Ethics in International Litigation, 113 AM. J. INT'L L. UNBound 312, 312 (2019) ("[W]e urge that states adopt a mandatory common code of ethics for disputes involving states, and that arbitral institutions adopt this code as part of their rules for administering arbitration.”). While a unified global approach may (or may not) lie in the future, state practice towards regulating arbitrators can already be seen. See, e.g., Norway Draft Model Bilateral Investment Treaty, art. 15, May 13, 2015, https://www.regjeringen.no/contentassets/e47326b61f424d4c9c3d470896492623/draft-model-agreemen t-english.pdf [https://perma.cc/2VU2-AYGT] ("Members of the Tribunal shall comply with the International Bar Association Guidelines on Conflicts of Interest in International Arbitration and any Code of Conduct adopted by the Joint Committee . . .."). NAFTA has a code of conduct for trade (but not investment) disputes, while CETA has one for its investment court. NAFTA Code of Conduct, supra note 125; Committee on Services and Investment Decision No. 1/2021 of 29 Jan. 2021 O.J. (L 59) 36.

188. One study counted over 6.5 third-party participants per case, although many do not make any submissions. Lauren Konken, Silence is Golden? Revisiting Third Party Participation in World Trade Organization Litigation 10 (Sept. 2018) (unpublished paper), https://www.peio.me/wp-content/ uploads/2019/01/PEIO12_paper_64.pdf [https://perma.cc/2RXD-VDP4] ("Looking at third party participants in completed disputes at the panel level and adjusting for duplicate cases yields 1140 instances of states acting as third parties across 170 disputes filed and concluded between 1995 and 2017.").

189. See U.N. Comm'n on Int'l Trade Law, Rep. of Working Group III (Inv'r-State Dispute Settlement Reform) on the Work of Its Thirty-Eighth Session, ๆๆ 67-78, U.N. Doc. A/CN.9/1004 (Oct. 23, 2019).

190. See Restatement (ThiRd) OF THE U.S. LAW OF INT'L COMMERCiAL \& INV'R-STATE ARBITRATION.

191. See Int'l Bar Ass'n [IBA], Rules of Ethics for International Arbitrators (1987). In this regard, the IBA might consider this an opportune time to update its 30 -year-old ethics rules, with detailed consideration of arbitrators' responsibilities to parties and non-parties alike.

192. See, e.g., ROGERS, supra note 19. 
Reform is the best hope for investment arbitration in this time of crisis, when even its leading traditional proponents threaten to exit the system. ${ }^{193}$ ICSID is making thoughtful efforts at reform, including the most significant overhaul of its arbitral rules to date. ${ }^{194}$ UNCITRAL is also coordinating a major reform project. ${ }^{195}$ Reform will have to be effected by the arbitrators, making it all the more important for states and institutions to clarify and uphold the duties they expect arbitrators to fulfill. ${ }^{196}$

\section{CONCLUSION}

The fact that the investment arbitration system imposes duties on arbitrators for the benefit of non-parties, sometimes over the preference of the parties, speaks profoundly about that system. These duties help reveal the system's nature, a system more akin to public adjudication than to a private matter controlled solely by and for the parties.

It is a system embedded within the overall structure of public international law. It shares with international law the elemental duty of good faith. The Vienna Convention describes the "principle[] of good faith" as "universally recognized." 197 Investment treaties, like all other treaties, must be performed in good faith and must be interpreted in good faith. ${ }^{198}$ Good faith "forms part of the foundation of the whole international legal structure," an "absolutely necessary ingredient." I99 It "a supreme principle, which governs legal relations in all of their aspects and content." 200 It pertains to

193. The EU and Canada are working to replace investment arbitration with a standing investment court. See Comprehensive Economic and Trade Agreement, Can.-E.U., art. 8.27, Oct. 30, 2016, 2017 O.J. (L 11) 23. The Trump Administration moved the other way, limiting investor claims in the NAFTA renegotiation. See, e.g., David A. GAntz, BAKer InSt. Pub. Policy, The United States-MexicoCANADA AgREEMENT: SETTLEMENT OF Disputes (2019).

194. See, e.g., Meg Kinnear, Sixth Annual Charles N. Brower Lecture on International Dispute Resolution: Procedure, Policy, \& Progress: Seeking Consensus on ISDS Rules Reform (Apr. 5, 2018), in 112 Proc. Am. SoC'y InT'L LAw ANNUAL MEETING 121 (2018).

195. See generally Stephan W. Schill, Investor-State Dispute Settlement Reform at UNCITRAL: A Looming Constitutional Moment?, 19 J. WORLD INV. \& TRADE 1 (2018).

196. The Draft Code thus missed two important opportunities. First, it omitted institutions from the list of persons to whom arbitrators owe their duties. See Draft Code, supra note 43, art. 3, para. 25. Second, it subverts other-regardingness by obliging arbitrators to "consider the best interests of the parties" without any counterbalancing consideration due to the interests of the public and interested nonparties. See id. art. 8(4).

197. Vienna Convention, supra note 85 , pmbl.

198. Id. arts. 26, 31 .

199. Michel Virally, Review Essay: Good Faith in Public International Law, 77 AM. J. INT’L L. 130, 133-34 (1983); Nuclear Tests Case (Austl. v. Fr.), Judgment, 1974 I.C.J. 253, \ 46 (Dec. 20) (“One of the basic principles governing the creation and performance of legal obligations, whatever their source, is the principle of good faith.").

200. Inceysa Vallisoletana, S.L. v. El Sal., ICSID Case No. ARB/03/26, Award, ๆ 230 (Aug. 2, 2006), 17 ICSID Rep. 100 (2016). 
international commercial law as well as public international law. ${ }^{201}$ And, to the point, good faith is inherent in the arbitral function. As Bernardo Cremades wrote in his article on "Good Faith in International Arbitration":

This principle [of good faith] affects both the parties to the dispute as well as the arbitrators or arbitration institutions or, in general, any person participating in the arbitral proceeding, whether as an attorney or an expert. ... [A]rbitrators and arbitration institutions must fulfill their role in good faith, protecting the integrity of the proceeding. ${ }^{202}$

Embracing this principle, ICSID has proposed a new "general duty": "The Tribunal and the parties shall conduct the proceeding in good faith. ..."203

Cremades concludes, "[T]he parties trust in the good faith of the arbitrators. ..."204 This is quite right, but incomplete. The parties trust in the good faith of the arbitrators and so do arbitral institutions, non-party participants, states, and the global public. Arbitrators in investment cases owe this overriding systemic duty of good faith to everyone and it permeates all that they do.

201. See LCIA Rules, supra note 14, art. 32.2 ("For all matters not expressly provided in the Arbitration Agreement, the LCIA Court, the LCIA, the Registrar, the Arbitral Tribunal and each of the parties shall act at all times in good faith, respecting the spirit of the Arbitration Agreement, and shall make every reasonable effort to ensure that any award is legally recognised and enforceable at the arbitral seat.") (emphasis added); Int'l Inst. for the Unification of Private Law [UNIDROIT], UNIDROIT Principles of International Commercial Contracts, art. 1.7 (2016) (“(1) Each party must act in accordance with good faith and fair dealing in international trade. (2) The parties may not exclude or limit this duty.”). UNIDROIT explains that the duty of good faith and fair dealing cannot be waived or limited because it is of "such a fundamental nature." $I d$. cmt. 4.

202. Bernardo M. Cremades, Good Faith in International Arbitration, 27 AM. U. INT'L L. REV. 761, 786-87 (2012).

203. ICSID Proposals, supra note 35 , r. 3(1), at 33.

204. Cremades, supra note 202, at 788. 